\title{
Deep volcanic morphology below Lanzarote, Canaries, from gravity inversion: New results for Timanfaya and implications
}

\author{
Antonio G. Camacho a , Juan F. Prieto ${ }^{\mathrm{b}}$, Eumenio Ancochea ${ }^{\mathrm{c}}$, José Fernández ${ }^{\mathrm{a}, *}$ \\ a Instituto de Geociencias (CSIC, UCM), Calle del Doctor Severo Ochoa, no 7, Facultad de Medicina (Edificio Entrepabellones 7 y $8,4^{a}$ planta), Ciudad Universitaria, 28040 Madrid, Spain \\ b ETS de Ingenieros en Topografía, Geodesia y Cartografí, Universidad Politécnica de Madrid, 28031 Madrid, Spain \\ c Departamento de Petrología y Geoquímica, Fac. CC. Geológicas, Universidad Complutense de Madrid, 28040 Madrid, Spain
}

\section{A R T I C L E I N F O}

\section{Article history:}

Received 8 June 2018

Received in revised form 6 November 2018

Accepted 19 November 2018

Available online 22 November 2018

\section{Keywords:}

Lanzarote

Canary Islands

Gravity measurements

3D density structure

Timanfaya

Plumbing system

\begin{abstract}
A B S T R A C T
The deep roots of oceanic island volcanoes are poorly known and geophysical models can help to constrain processes such as magma storage and transport before and during eruptions. Lanzarote, Canary Islands, is a volcanic island in post-erosional phase where, in the 18th century, one of the most important historical eruptions, considering duration and volume, of the Canary Islands took place in the Timanfaya area. To improve the knowledge on the structure of Lanzarote and in Timanfaya area, we carry out a gravity determination of the subsurface anomalous 3D density structure, using an improved quasi-automatic inversion methodology. The obtained model presents a 3D morphology of anomalous density bodies. We describe the improvements of the inversion methodology, the adjusted model and interpretative conclusions corresponding to the structure and the longterm cumulative magmatic plumbing system of the island. Three high-density sources are described as resulting in the inference of three main volcanic complexes: a large central complex (San Bartolomé) and two smaller complexes, one in the NE and a third smaller one located in the SW close to the Timanfaya area. The outcrops of Miocene lava flows from the center of the Island can be attributed to the top of the central intrusive model. We infer the local plumbing system for Timanfaya volcano area by means of strongly tilted successive branches of magma departing from the SW intrusive body. The structural results show no evidence of any magma chamber below Timanfaya as proposed by previous works. We also present a comparison of the gravity results and geological observations, showing different cases of correlation in the Island. They go from a good match between the gravity anomaly and the position of the central volcanic structure, to no anomaly associated to the fissural Quaternary volcanic activity.
\end{abstract}

(c) 2018 Elsevier B.V. All rights reserved.

\section{Introduction}

The deep internal structure of active oceanic volcanic islands is a problem which remains unresolved (Leahy and Park, 2005; Lodge et al., 2012). Oceanic islands are formed by voluminous magma supply from the mantle, resulting in large and complex edifices and volcanic structures. During successive injections of magma pulses into the shallow lithosphere, mafic magmas build up within the upper mantle and lower crust and core complexes arise within the island's crust (Hansteen et al., 1998). Due to the buoyancy effect, a column of magma with a lower density than the wall material can break the surrounding rock once it reaches a critical length. Hydraulic fracturing in the upper mantle produces rapid and self-propagating upward displacement of magma dikes until the level of neutral buoyancy (LNB) is reached (e.g., Lister and Kerr, 1991). New magma accumulation leads to lateral propagation close the LNB, forming dikes when the least

\footnotetext{
* Corresponding author.

E-mail address: jft@mat.ucm.es (J. Fernández).
}

compressive stress is vertically orientated and sills when the LNB is close to horizontal layers of weakness such as sediment or foliated gabbros (Hansteen et al., 1998).

Areas of magma ascent, in large volcanic regions, are characterized by abundant sub-volcanic rocks from plutons formed when magma reservoirs are retained in the crust during ascent. Fisher and Schmincke (1984) estimate that about $80 \%$ of the magmas that form oceanic intraplate environment fail to erupt. These intrusive bodies are normally denser than the volcanic rock in which they fit, so positive gravity anomalies can tell us about the preferred areas of magma ascent throughout the volcanic complex's evolution. In oceanic islands the main volcanic edifices are usually of two types: (a) large central edifices (shield volcano or composite volcano), formed by magma ascending by means of swarms of dikes with radial geometry, or sills; and (b) rift zones, formed by dikes intruding parallel to the direction of the rift. Canary Islands show many examples of these structures (e.g., Ancochea et al., 1996, 2003), which are usually mixed, a central edifice with swarms of radial dikes, but preferably concentrated along rifts in three main directions spaced about $120^{\circ}$ from each other, with a three- 
pointed star geometry (Navarro and Farrujia, 1989; Carracedo, 1994, 1999; Walter et al., 2005).

The large volcanic complexes in the Canaries evolved over a very long period of time, which is why there can be several central edifices on the same island, or why the edifices change from rift to central type (Ancochea et al., 2008).

The structure of these great volcanic edifices can be deduced from different kinds of surface data. In recent volcanic areas (Plio-quaternary), most of the information is obtained from the analysis of volcanic morphologies and distribution of volcanic vents. In older volcanic areas, erosion, tectonic or large landslides, so frequent in this type of islands, provide access to the innermost area of the islands and direct information can be gained essentially from the distribution and chronology of the various volcanic stratigraphy units and magmatic bodies, such as dikes or small plutons. However, this is not always possible, and, in any case, deeper areas can only be reached through indirect observation, using different geophysical techniques.

Many usual volcanic structures involve density anomalies. Rymer and Brown (1986) suggest that positive gravity anomalies correspond usually to relatively dense intrusive magma bodies below magmatic volcanoes. Negative anomalies are detected corresponding to pyroclastic and lava flow deposits, and caldera infill material.

This study aims to produce a 3D gravity model for the Lanzarote density structure, placing special emphasis on the Timanfaya volcano area (where new data are available), designed to provide information (among other aspects, about the island's plumbing system or systems) for use as models that can be extrapolated to other volcanic islands. In this sense, the island of Lanzarote has unique features that make it an ideal laboratory for this type of studies:

- It had volcanic activity for many of million years, and subaerial during the last 15 Ma (Coello et al., 1992).

- The island is not the result of the growth of a single volcanic structure, but the combination of several volcanic structures, with different evolutions, and parallel to the African coast (Ancochea et al., 1996).

- Almost all of the island's geology is known (e.g., 1:25,000 geological maps of the whole island; IGME, 2005) and there is a reasonable amount of geochronological data.

- It is the Canary Island that has had the most important historical eruption (the Timanfaya eruption).

- There is a significant amount of gravity data (Camacho et al., 2001, 2017).

- The island does not have any significant relief, which greatly simplifies the topographic correction of the gravity measurements and therefore the interpretation of the anomalies obtained.

- The island does not have a single gravity anomaly, but several important and separate anomalies. Two of them located in interior zones, and a third one of peripheral character (Camacho et al., 2001).

- The location of the anomalies does not always match the locations of the visible volcanic structures.

Also, from the methodological point of view, we use a more advanced gravity inversion methodology to carry out the modelling (Camacho et al., 2011a, b) specifically improved for this study and new data for Timanfaya area (Camacho et al., 2017).

All these aspects make it easier for the results obtained for Lanzarote, which are important per se, to be generalized for other islands of the Canary archipelago and other areas. The deep roots of oceanic island volcanoes are poorly known and better geophysical models could quantitatively constrain processes such as magma storage and transport during and before eruptions. From a volcanic hazard perspective, knowing the volcanic island's subsurface structure could help to understand the current magmatic plumbing system (see e.g., Galindo et al., 2016). It could also have dynamic implications on the evolution models of oceanic islands.

\section{The Canary Islands and Lanzarote}

The Canary Islands archipelago (Fig. 1a) is a $500 \mathrm{~km}$-long string (similar to the Hawaiian archipelago) of seven intraplate volcanic islands, located above a Jurassic-age oceanic crust, close to the West African continental margin. Their origin is still controversial and different types of genetic models have been proposed for the archipelago (e.g., Wilson, 1973; Anguita and Hernán, 1975, 2000; Schmincke, 1982; Holik et al., 1991; Geldmacher et al., 2001; Gripp and Gordon, 2002; Van den Bogaard, 2013).

In the well-accepted models for the evolution of the Hawaiian Islands, individual islands formed through several geomorphic evolutionary phases: a seamount phase, a submarine and subaerial shield-edifice phase with fast growth and major slope failures, a period of quiescence and intense erosion (erosional gap), and a post-erosional stage of volcanic activity. Broadly speaking, these models are valid for archipelagos similar to the Hawaii islands, where each island is formed in a very short space of time (usually lasting circa $1 \mathrm{Ma}$ according to Langenheim and Clague, 1987) and oceanic plates move at significant speed.

However, the islands of the Central Atlantic archipelagos, such as the Canary Islands and Cape Verde, have formed over many millions of years and the plates have moved much more slowly. Therefore, although for these islands one can speak of seamount phases, shieldedifice phases and sometimes post-erosional phase (e.g., Carracedo, 1999), their actual structure is acknowledged as being much more complex, with multiple phases of growth and very different edifices overlapping over time and space (e.g., Ancochea et al., 1996). The multiple growth phases are accompanied by large chemical diversity (e.g., Hoernle and Schmincke, 1993), suggesting diverse mantle sources and plumbing systems.

Lanzarote and Fuerteventura are the oldest, easternmost islands of the archipelago (Fig. 1a). They were formed by volcanic processes occurring on the western margin of the Triassic rift basin that arose during the initial opening of the Central Atlantic (Martínez del Olmo and Buitrago Borrás, 2002). Volcanic activity may be as old as 70-80 Ma (Le Bas et al., 1986) on these eastern islands, which are the emergent part of the East Canary Ridge (ECR) (Dañobeitia, 1988), a NNE-SSW linear volcanic structure on a typical oceanic crust, at least $11 \mathrm{~km}$ thick (Banda et al., 1981), located between the continental rise and the Canary basin. East of the ridge, the continental rise is composed of a sedimentary succession $>10 \mathrm{~km}$ thick (Watts, 1994). The general uplift trend on both islands is about $1.7 \mathrm{~cm} / \mathrm{ka}$ for the last Ma (Zazo et al., 2002). Watts (1994) suggests some uplift, concentrated locally within the Canary archipelago region rather than over a broad region, due to a narrow plume. For Grunau et al. (1975) the East Canary Ridge is formed by several blocks of oceanic basement uplifted and covered by a thick pile of volcanic rocks. Ancochea et al. (1996) indicate that it is a succession of volcanic complexes, sometimes submarine and other subaerial, with independent growth phases and each with its own internal intrusive complex.

Lanzarote is the north-easternmost large island of the archipelago. It consists of a shallow basement, whose depth (about 4-5 km) was estimated from seismic profiles (Banda et al., 1981). North of Lanzarote there are three smaller islands: La Graciosa, Montaña Clara and Alegranza, which together with two other islets are called the Chinijo archipelago and are geological continuity with the island of Lanzarote.

Lanzarote has three main morphological and geological sectors. The Los Ajaches and Famara massifs lie at the southern and northern ends respectively (see Fig. 1b). These two reliefs are just over $600 \mathrm{~m}$ above sea level, the highest of the island, and are formed by the accumulation of Miocene or Pliocene lava flows and pyroclastic, and in both cases inclined $2^{\circ}$ to $8^{\circ}$ to the E and SE. They correspond to two separate volcanic complexes and lying between them, occupying most of the surface, is a lowland area of 100-200 m altitude, which includes many isolated, quaternary age (Pleistocene or Holocene) volcanic cones, and whose lava flows cover most of the area (Fig. 1b and c). 
a

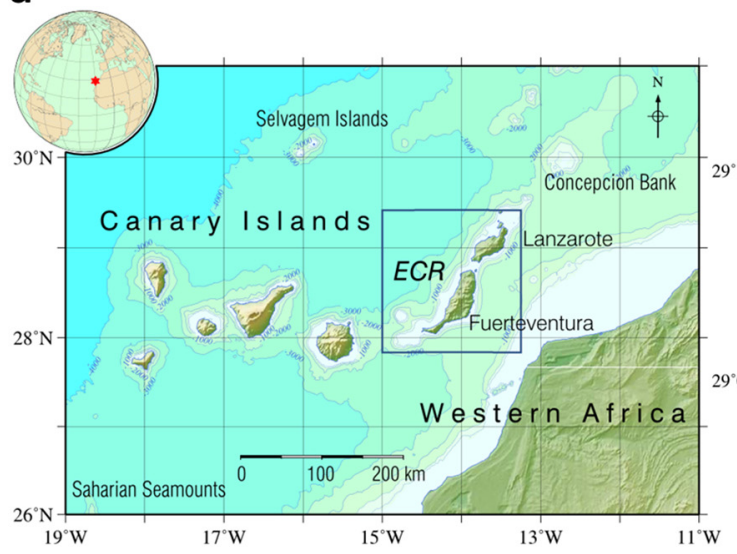

b

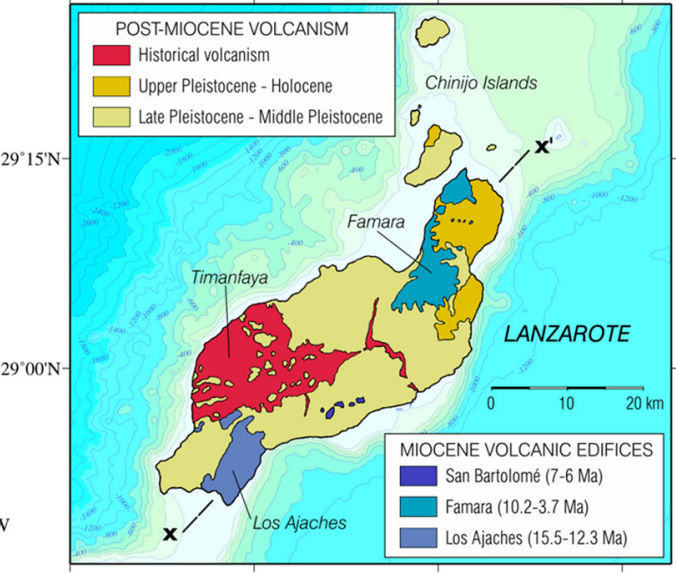

$14^{\circ} 00^{\prime} \mathrm{W}$

$13^{\circ} 45^{\prime} \mathrm{W}$

$13^{\circ} 15^{\prime} \mathrm{W}$

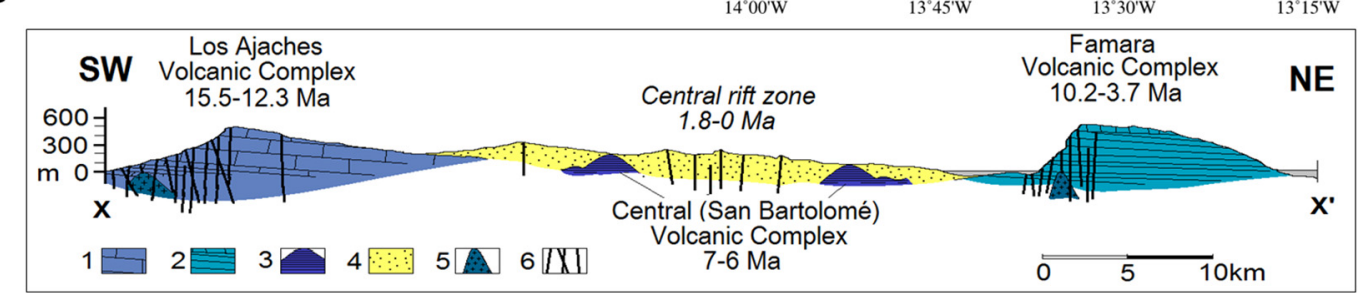

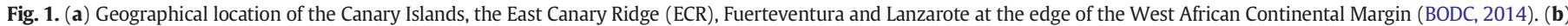

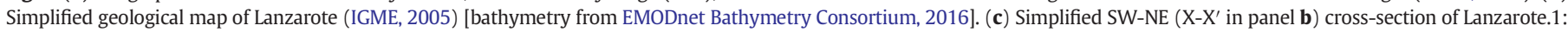
Los Ajaches volcanic complex. 2: Famara volcanic complex. 3: Central Volcanic Complex. 4: Central rift zone. 5: Intrusions. 6: Dikes.

The age of the Los Ajaches Volcanic Complex (AVC) is entirely Miocene, essentially from 15.5 to 12.3 Ma (Abdel-Monem et al., 1971; Ibarrola et al., 1988; Coello et al., 1992). Conversely, in the Famara Volcanic Complex (FVC), Coello et al. (1992) distinguish three phases of growth, all younger than Los Ajaches: the bottom between 10.2 and 8.3 Ma, intermediate between 7.2 and $5.3 \mathrm{Ma}$ and top with between 3.9 and 3.7 Ma. The oldest eruptions of the central area of the island have been dated at $1.8 \mathrm{Ma}$ and have continued to the present, the last being in 1824 (Ibarrola et al., 1988; Coello et al., 1992; Zazo et al., 2002).

If we fit this data into a standard "Hawaii type" evolution model, we would have a first shield-edifice phase between 15 and $12 \mathrm{Ma}$, only in the south of the island, which would lead to AVC. The rest of the island of Lanzarote would not exist or would be submerged beginning to form its seamount phase. From 12 Ma there are no data on volcanic activity in southern Lanzarote, and AVC erodes, forming gullies and revealing a part of the dikes where the magma that created the volcanic edifices built up. Between 10 and $4 \mathrm{Ma}$, when the activity in Los Ajaches was over, a new island would have grown in North Lanzarote: Famara, formed by a volcanic complex, where activity breaks and erosion can be distinguished.

It would have been a new shield phase, not related to the previous shield phases in southern Lanzarote. Between 4 and 2 Ma, activity would have ceased again, now throughout Lanzarote, and a major erosive phase began. Activity resumed in the last two million years in the central area of Lanzarote. This new activity could be considered to correspond to a post-erosive phase, since it is formed after the erosion of two large volcanic complexes.

Some accumulations of basaltic flows without dikes that extend across the southern half of the island and have been dated between 6 and $7 \mathrm{Ma}$ (Coello et al., 1992), are to be found in the middle of the island, between the products of the Pleistocene and Quaternary eruptions, covering almost the entire area, in erosional windows. They are clearly after AVC and simultaneous with a portion of FVC, but far from it. Their interpretation that it forms part of FVC or a different volcano (Central Volcanic Complex, CVC, Fig. 1c) needs to be clarified.
According to Armenti et al. (1989), the island of Lanzarote is cracked by NNE-SSW and NE-SW faults. The greatest principal stress, with ENEWSW direction, suggests a transpressive regime. The NE-SW striking faults would be generated by extensional tectonics and minor transcurrence component.

From a volcanic hazard perspective, knowing the volcanic island's subsurface structure could help to understand the current magmatic plumbing system. In particular, the Timanfaya 1730-1736 eruption was one of the Earth's biggest historical eruptions. This eruption covered a large part of the western Lanzarote under thick lavas flows and large pyroclastic cones. A magnetotelluric study of Timanfaya showed a highly conductive body, approximately $4 \mathrm{~km}$ deep, which was interpreted as a shallow magma chamber dating back to the 1730 to 1736 CE eruption (Ortíz et al., 1986). In addition, Díez Gil et al. (1986) used thermal anomaly data to propose a $200 \pm 100 \mathrm{~m}$ radius magmatic intrusion, at a depth of $4 \pm 1 \mathrm{~km}$, characterized by a convective system where energy is carried by fractures which continue in depth. Surface temperature in Islote de Hilario (IH in Fig. 2b) ranges from 100 to 600 ${ }^{\circ} \mathrm{C}$ at a depth of $13 \mathrm{~m}$.

\section{Gravity data, gravity anomaly, inversion approach and model}

Gravity data used in our study are composed of two subsets observed at different times, with 465 stations (Camacho et al., 2001, 2017). In the following sub-sections we present a full description of data, a description of the gravity anomalies, the improved inversion approach, some basic characteristics of the resulting inverse model and an uncertainty analysis of the inversion results.

In the next section, we present and discuss the inverse model results obtained applying the described inversion software to the gravity data from Timanfaya and the whole Island of Lanzarote. They are shown using different figures representing cross-sections and perspective views, which will illustrate characteristic features. In the figures we only represent the areas where the obtained results have reasonable confidence values (see Section 3.3). 


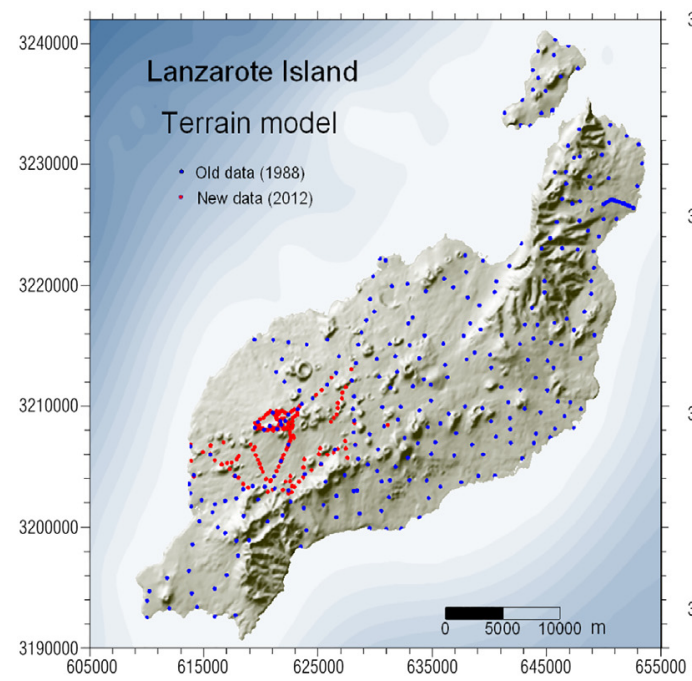

(a)

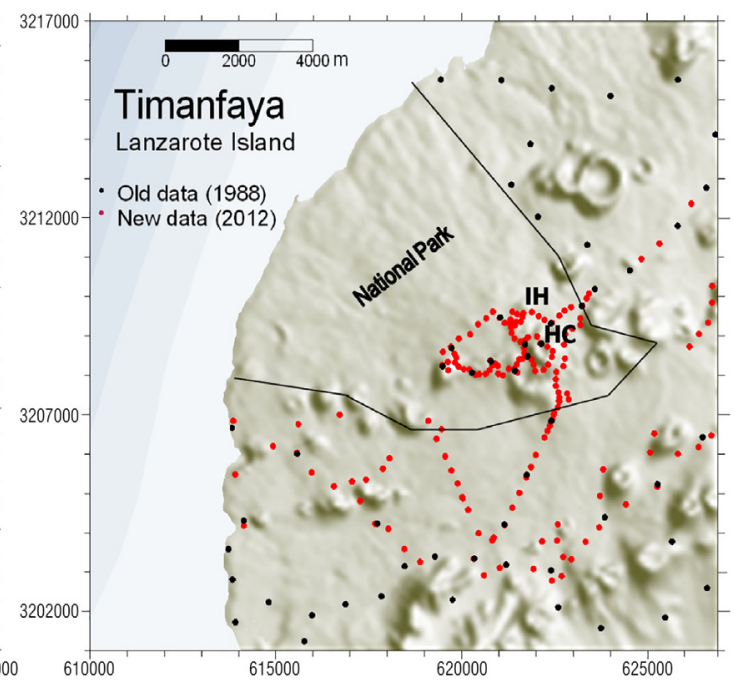

(b)

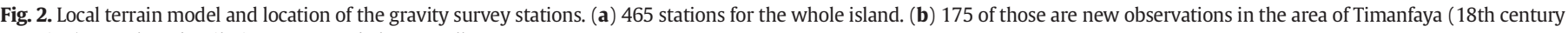
eruption). IH: Islote de Hilario, HC: Hoya de los Camelleros.

\subsection{Gravity data and gravity anomaly}

Gravity data, measured at 465 stations, are composed of two subsets: the data from the survey carried out for the whole island of Lanzarote in 1988 (290 stations), with a mean step of about $2 \mathrm{~km}$ (Camacho et al., 2001), and a new set of observations carried out in 2012 for the area of Timanfaya (TI) (175 stations) and with a mean step of $500 \mathrm{~m}$ (Fig. 2) (Camacho et al., 2017).

The 1988 gravity observations were registered with a LaCoste\&Romberg instrument, but the corresponding elevation values were determined by reading local topographic charts (Camacho et al., 2001). This data set has been carefully reprocessed. We have determined and corrected for some tares or jumps in the gravity record during the survey (probably due to brief thermostatization faults), and adjusted the instrumental drift. The adjusted gravity values have an uncertainty estimation of about $\pm 0.22 \mathrm{mGal}\left(1 \mathrm{mGal}=10^{-3} \mathrm{~m} / \mathrm{s}^{2}\right)$. The horizontal position of the station has been taken from the original determination on topographic maps, but the elevation has been determined by interpolation on a digital elevation model (DEM) with a $25 \mathrm{~m}$ step (MDT25) from the Spanish Instituto Geográfico Nacional, on REGCAN95 geodetic reference frame (www.ign.es). We estimate a precision of about $\pm 2 \mathrm{~m}$ for this elevation data.

The new observations were carried out during two field surveys in March and December 2012, and which mainly focused on the area close to the Timanfaya volcano. Gravity measurement points were measured using a Scintrex CG-5 instrument. The corresponding positioning was carried out with two GPS geodetic receivers, providing elevation data within $\pm 0.05 \mathrm{~m}$ accuracy. The global traverse fit of the gravity observations can be used to determine the instrumental drift and to estimate the precision of the adjusted gravity values as $\pm 0.04 \mathrm{mGal}$.

Once both data sets were homogenized (by using common stations) and referred to an external gravity reference (IGSN71), we determined the gravity anomaly. First, normal gravity was referenced to GRS80 (Geodetic Reference System 1980). Next, the Bouguer and terrain corrections were calculated, adopting a mean terrain density value of $2300 \mathrm{~kg} / \mathrm{m}^{3}$. This terrain density value was determined from seismic refraction data by MacFarlane and Ridley (1969) as a realistic value for the upper layer of the crustal structure. Nevertheless, Lanzarote is a quite flat island. The root mean square (rms) deviation of the terrain correction values $(1.5 \mathrm{mGal})$ is small compared with respect to the strong anomaly signal (with an rms deviation of $15 \mathrm{mGal}$ ). Therefore, discrepancies in the mean terrain density would have little effect on the anomaly and on the inverse model for anomalous density. Similarly, other inaccuracy sources (mainly elevation inaccuracy) produce a small relative effect. The gravity terrain correction is applied upon merging the MDT25 data for on-shore Lanzarote plus bathymetric data loaded from the ASCII files provided in http://topex.ucsd.edu/cgi-bin/get_ data.cgi from Geosat and ERS 1 satellite altimetry (Sandwell and Smith, 1997). Computations are extended up to a distance of $60 \mathrm{~km}$ away from each gravity station. The obtained values range in a root mean square (rms) deviation of $1.5 \mathrm{mGal}$ with an average value of about 5.0 mGal.

Fig. 3a shows a map of the obtained gravity anomaly for the entire island with a strong signal, in a range of $75.8 \mathrm{mGal}$ between extreme maximum and minimum values. The island's anomaly is characterized by a central sharp high, and two additional relative highs located in the northeast and southwest, respectively. Fig. 3b depicts a zoom of the Bouguer anomaly for the Timanfaya area.

For the further gravity inversion approach, we include both gravity data sets, the old and the new sets. The quality of the gravity values is similar for both sets (similar instrument, similar observation process, similar correction calculus). The main quality difference comes from the elevation quality. We have tried further inversions considering different weights for both sets of data (double for the new set). Final resulting models are very similar.

\subsection{Gravity inversion approach: Inverse model}

The observed anomaly corresponds to the gravity effect of some anomalous density structure beneath the island surface. The fit of a suitable geometrical distribution of anomalous density, capable of reproducing the observed gravity anomaly $\left(\Delta g_{i}\right.$ at $n$ benchmarks $\left(x_{i}, y_{i}, z_{i}\right)$ ) can be obtained by some inverse gravity approach. In previous papers (Camacho et al., 2000, 2002, 2007, 2011a, b), a gravity inversion methodology has been presented, tested and applied in different study cases. That inversion process constructs a subsurface model defined by a 3-D aggregation of $\mathrm{m}$ parallelepiped cells, which are filled, in a "growth" process, by means of prescribed positive and/or negative density contrasts $\Delta \rho_{j}^{+}$and $\Delta \rho_{j}^{-}, j=1, \ldots, m$. In order to select a valuable particular solution from among the infinite set of possible solutions from the observed data, we adopt a mixed minimization condition, based on model "fitness" (least square fitness) and "smoothness" (total anomalous mass). The operative inversion approach is based on a mathematical exploration of the model space [in the sense of Tarantola, 1988] for 


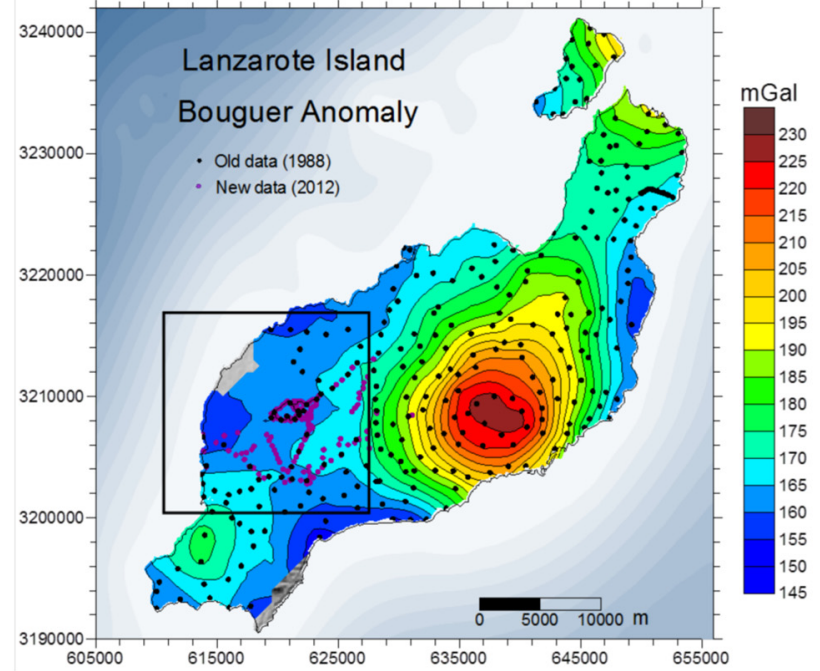

(a)

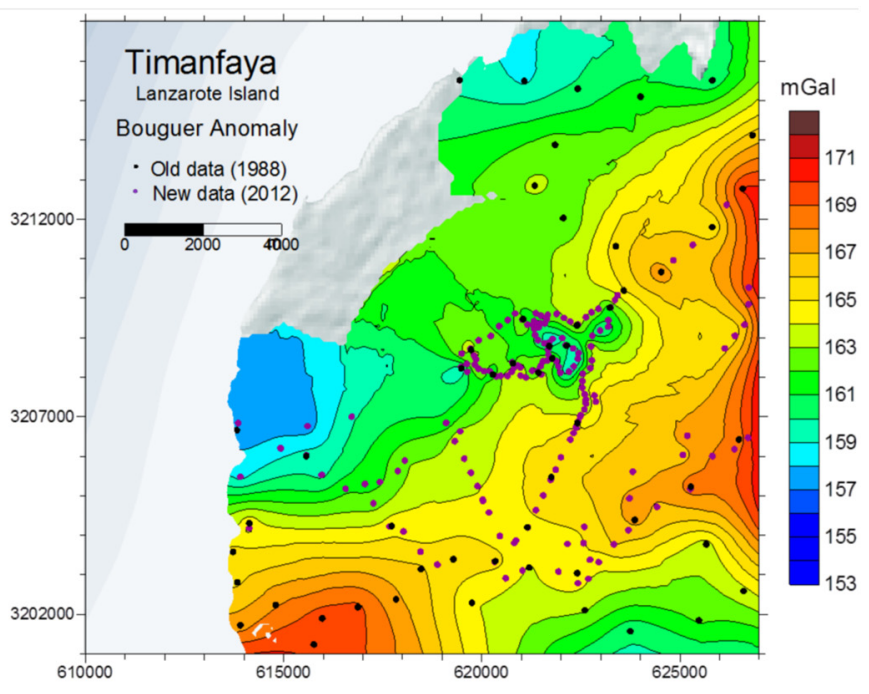

(b)

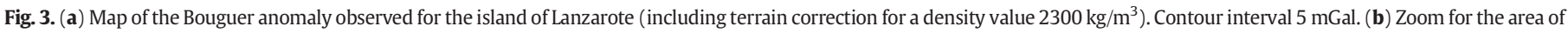
Timanfaya depicted in panel (a). Contour interval $1 \mathrm{mGal}$. Dots indicate the location of the gravity measurements.

defined density contrasts. Characteristics of the method are as follows: (1) solution for 3-D model space, (2) acceptance of non-gridded nonplanar imprecise data, (3) simultaneous inversion for both positive and negative density contrasts, (4) inversion for irregularly-shaped structures composed of several individual bodies, (5) semi-automated data inversion routine, without subjective or previous information. This inversion routine was implemented and made available in the software package GROWTH by Camacho et al. (2011a), enabling the user to load and invert gravity anomaly data and graphically display the inversion results. An early version of this inversion approach was applied to the initial data for Lanzarote anomaly to get some structural model for anomalous density distribution (Camacho et al., 2001).

However, the former methodology and software determine the geometry of the anomalous structures with respect to a homogeneous background medium. It is not very realistic, and adjusted anomalous density bodies appear isolated, and in rather shallow position, without any deeper root. They remain suspended in a homogeneous medium.

A more realistic modelling can be obtained by adjusting the anomalous structures as immersed in a medium with general downward density increase. It looks a more acceptable background for general medium structure.

Camacho et al. (2011b) present a modified methodology capable of dealing with this advanced modelling. A valuable option would be to select and apply some published layered crust structure. In this sense, for instance, van der Meijde et al. (2003), using data teleseismic receiver functions (RF), identify three discontinuities beneath Lanzarote at depths of $5 \mathrm{~km}, 11 \mathrm{~km}$ and the Moho at $19 \pm 1.5 \mathrm{~km}$. However, Lodge et al. (2012) assure that RF analysis is controlled by the back azimuthal coverage and at Lanzarote it was not sufficient to determine any more than a gradational velocity model, with discontinuities at $\sim 4, \sim 10$ and $18 \pm 1.5 \mathrm{~km}$ depth (the Moho). To avoid our results depending heavily on the assumed model for layered crust, we have rejected the approach of considering a very precise a-priori defined model for the step density change. Instead, we have adopted a continuous density increase with depth. This approach allows for a suitable modelling and prevents dependence on very detailed assumptions. The present paper includes a modification of the general inversion methodology to include a background medium with continuous downward density increase. Operatively, first the process adjusts a model with inner downward density decrease immersed in a homogeneous model (Fig. 4a). Second, a global downward density increase is applied to the entire model (anomalous structure and medium) giving rise to the final model (Fig. 4b).

Apart from the former downward continuous density increase, here we also propose two additional modifications concerning the model density contrast.

First, we propose assuming a lateral smoothing of the anomalous bodies, in the sense of an attenuation of the density contrast in the periphery of the anomalous bodies. This can be easily attained by decreasing the density contrast in the final phases of the growth approach. This modification allows us to model smaller morphological details.

Second, we look for a free adjustment of the basic density contrast (instead of assuming an a priori value). So, instead of fixed values for density contrasts $\Delta \rho_{0}^{+}$and $\Delta \rho_{0}^{-}$everywhere, we propose now to use in the pointed inversion methodology a variable density contrast values, positive and negative $\Delta \rho_{j}^{+}$and $\Delta \rho_{j}^{-}$, given, for the fit the $\mathrm{j}$-th cell at the growth step $k$-th, by:

$\left(\begin{array}{c}\Delta \rho_{j}^{-} \\ \Delta \rho_{j}^{+}\end{array}\right)=\left(\begin{array}{c}-1+\theta_{j} \\ +1+\theta_{j}\end{array}\right) \varphi_{k} f$

where $f \geq 1$ is a scale factor (Camacho et al., 2011a, b) that allows to relate a basic density contrast close to $1(-1$ and +1$)$ with the final suitable density contrast. This scale factor is an unknown parameter in the growth approach, and it is adjusted for each step of the process according the minimization conditions. We allow for a free decrease of the model scale factor $f$ (Camacho et al., 2011a). Instead of taking $f=1$ as end condition, the approach ends when it is not possible to add any cell that reduces the misfit value.

$\theta_{j} \geq 0$ is an incremental density value which allows to include the downward density increase of the medium at the $j$-th cell. We adopt an exponential function on the depth $z_{j}$ for the $j$-th cell

$\theta_{j}=C \exp \left(z_{j}-z_{T}\right)$

$z_{T}$ being a depth value for the model top. $C \geq 0$ is a coefficient whose value is set a priori. Suitable values for $C$ can be chosen by inspecting the resulting model and looking for reasonable general geometry (avoiding as possible high density structures located above structures with smaller resulting density or low density structures located below 


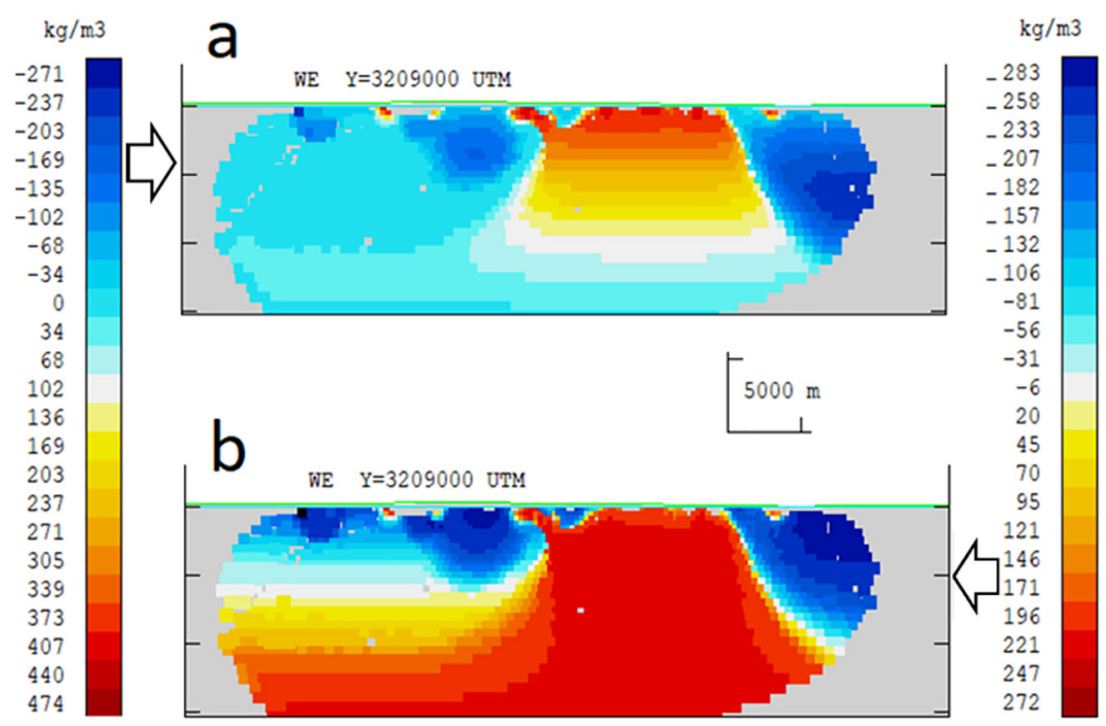

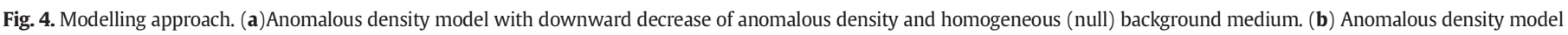
obtained from model (a) by adding globally a downward density increase (medium and model).

structures with higher density). $C=0$ correspond to homogeneous background medium.

$\varphi_{k} \geq 1$ is a factor for lateral attenuation along the growth approach. We write it, for the $k$-th step of the growth process $(k=1,2, \ldots)$, as a quadratic function of the $k$ values:

$\varphi_{k}=1-(D k)^{2}$

where $D \geq 0$ is a coefficient whose value is set a priori. For $D=0$, anomalous bodies become homogeneous, with a sharp density change on their borders. For $\mathrm{D}>>0$, the geometrical limits of the threedimensional bodies appears rather diluted, and the model show a gradual transition of density from the values inside the anomalous body until the values in the surrounding medium.

This modified modelling approach produces interesting inverse models, in a nearly automatic process, with very few a priori assumptions. Here we have applied this advanced approach to the case of Lanzarote.

The resulting inverse model for Lanzarote is composed by about 120,000 small parallelepiped cells (nearly cubes) with side of about $400 \mathrm{~m}$. In the following Figs. 7 to 11 , corresponding to the resulting model, it is possible to appreciate the discretization in very small cells. The obtained model is composed by several anomalous high density bodies and several anomalous low density bodies. The maximum anomalous density contrast required by the inversion approach is about $800 \mathrm{~kg} / \mathrm{m}^{3}$. This model fits the observed (weighted) anomaly for Lanzarote within $\pm 0.50 \mathrm{mGal}$, which is at the rms residual level. Residual values are uncorrelated and will correspond to very local and shallow heterogeneities, and to inaccuracies (mostly elevation or terrain correction) in the data, see the residuals map shown in Fig. 5.

\subsection{Uncertainty analysis of the inversion results}

The general inversion approach to get the density anomaly model has been repeatedly tested with synthetic studies and with real application cases, from its first version until the current, more sophisticated version. See for instance the papers (Camacho et al., 2000, 2002, 2007, 2009, 2011a, b; Tiede et al., 2005; Gottsmann et al., 2008; del Potro et al., 2013; Hautmann et al., 2013).

Simulation tests show good agreement between the synthetic bodies and the adjusted model, within some expected limitations. The deepest, most peripheral portions offer a worse fit than the central portions. Even more, the methodology includes some smoothing constrains, which give rise to rather rounded anomalous bodies, mainly again for the deepest and/or most peripheral areas. Those results show that the modelling approach gives reasonable results. Nevertheless, we cannot forget that gravity inversion is an ambiguous problem with nounique solution.

Apart from the synthetic test results using the inversion methodology, for the particular case of Lanzarote data, the confidence in the inversion modelling results is based on several facts:

(1) We have a large set of data, obtained by the authors who carried out the field work (gravity and positioning) and the further process to get the anomaly values (GPS data processing, tidal corrections, instrumental drift corrections, latitude and altitude reduction, and terrain effect corrections) (Gottsmann et al., 2008; Camacho et al., 2017).

(2) Due to the lack of strong relief in the island, the terrain effects (which are usually rather difficult to manage) are small (an average value of $5 \mathrm{mGal}$ ).

(3) The observed gravity anomaly corresponds to a strong signal (with a range of $76 \mathrm{mGal}$ between extreme maximum and minimum values) with an estimated accuracy of $0.8 \mathrm{mGal}$.

However, this confidence of the model is not homogeneous. The gravity attraction depends heavily on the distance between the observation points and the causative body. The deepest, most peripheral portions have a smaller relative confidence, and provide a more rounded geometry than the central portions.

Fig. 6 graphically shows the relative confidence by plotting the model sensitivity. It provides values of mass (in $10^{9}$ Metric Ton, MT) for the causative structure to produce a root squared mean value of $1 \mathrm{mGal}$ in the available data points. For a density contrast of $1000 \mathrm{~kg} / \mathrm{m}^{3}, 10^{9} \mathrm{MT}$ correspond to $1 \mathrm{~km}^{3}$. In Fig. 6 we see that the sensitivity of the gravity survey (and then the uncertainty of the model) depends heavily on the depth and on the distance to the survey area. For a density contrast of $1000 \mathrm{~kg} / \mathrm{m}^{3}$, below the survey area, and for the region between $2 \mathrm{~km}$ and $10 \mathrm{~km}$, the sensitivity range is between 5 and $40 \mathrm{~km}^{3} / \mathrm{mGal}$. According to these estimates, and according the estimated accuracy of the surveys, in general terms size details of about $1.5 \mathrm{~km}$ would be sensitive in shallow areas and size details of about $4 \mathrm{~km}$ would be sensitive in deep areas.

We can note that some clear patterns observed in the shallowest horizontal sections do not appear so clearly in the deeper sections. 


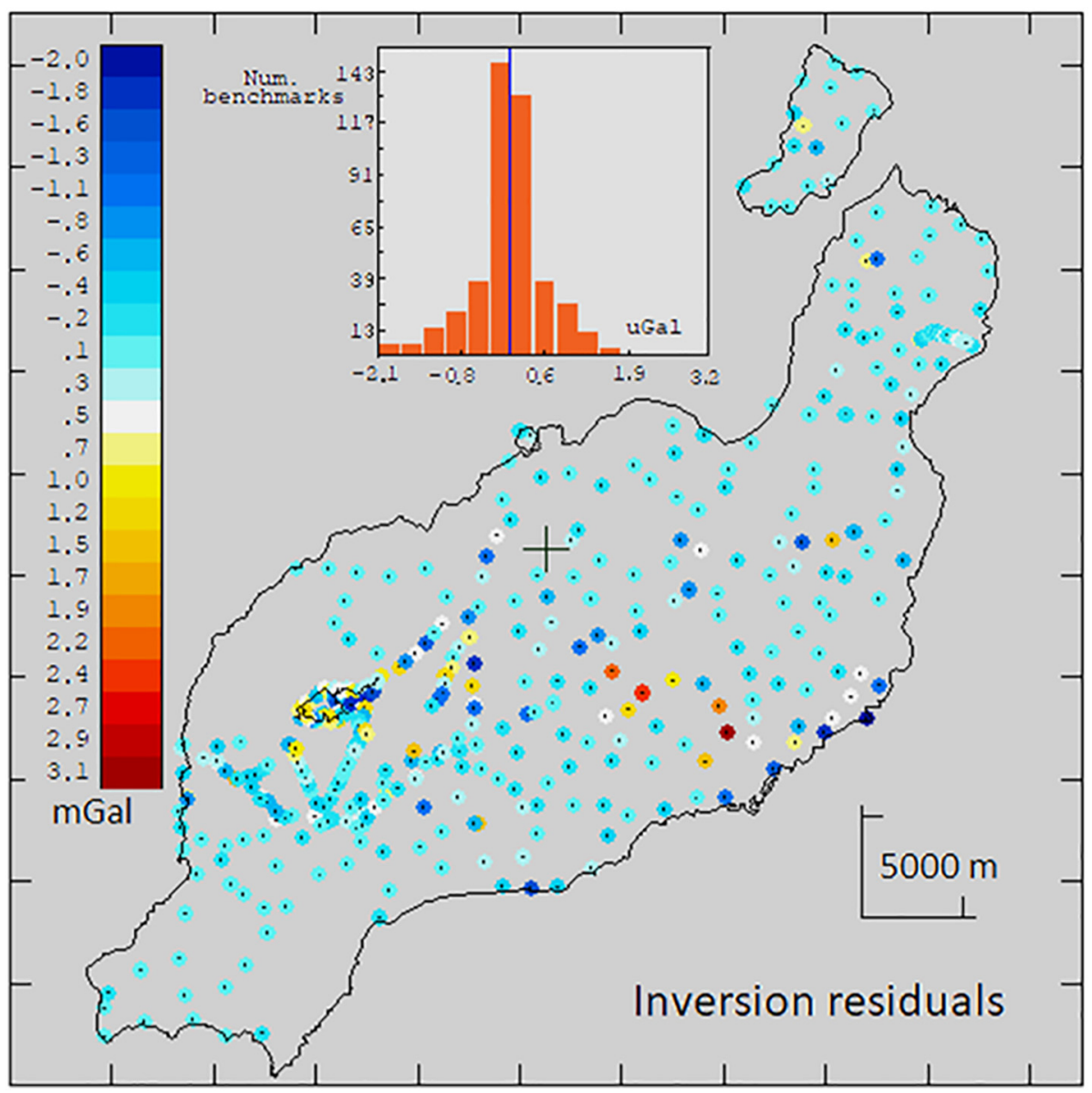

Fig. 5. Map of the residuals (mGal) of the fit. The inserted square in the upper part shows a histogram with the number of observation points vs. residual size in $\mu$ Gal.

However, this is not due to the non-existence but rather mostly to the smoothing effect with the depth in the modelling.

Regarding the robustness of the structure results, we must consider that the mean distance between neighbouring gravity stations conditions the availability of the model to appreciate very shallow details. There is a very shallow shadow portion. For the whole island the mean distance between stations is $2000 \mathrm{~m}$, meanwhile for the Timanfaya area it is $500 \mathrm{~m}$. There is a clear difference of reliability in the upper part of the model for both areas.

However, it can be considered that all significant morphological details described in the main text have enough presence in the model (in spite of the confidence and smoothing heterogeneities in the model) to be considered as close to reality.

\section{Discussion of results: high density complexes}

In this section, we present and discuss the inverse model results obtained by applying the described inversion process to the gravity data from Timanfaya and the whole Island of Lanzarote. They are shown using different figures representing cross-sections and perspective views that will illustrate characteristic features.

Our interpretation of the inverse model for anomalous density in Lanzarote is mostly based on the hypothesis of Walker (1999). He suggests that, in most volcanoes, rift zones and underlying dike swarms include the paths followed by magmas travelling through the crust. Most of these intrusive complexes may contain thousands of narrow dikes or other sheet-like intrusions or swarms positioned and oriented by tectonic structures or propagated laterally from volcanic centers along rift zones, following neutral buoyancy levels. Dike complexes grow incrementally as magma dikes are aggregated along their margins
(Walker, 1999). Sheet intrusions closer to the surface (dikes and sills) are conduits that carry magma from the reservoirs to the surface or to shallow intrusions, which are well documented for active volcanoes, such as Kilauea or Piton de la Fournaise (Malengreau et al., 1999). According to Walker (1999), swarms of intrusive dikes can produce some bending or start a rift zone. Ryan (1987) and Malengreau et al. (1999) suggested that intrusive complexes and cumulates beneath the volcano develop upwards as a volcano grows. According to Rymer and Brown (1986), volcanic positive gravity anomalies are due to relatively dense intrusive complex/magma body below basaltic volcanoes. In short, below the center of a mature oceanic shield volcano we would find a column-like body of relative high-density rock that can be detected through gravity observation and modelled by an inversion approach.

In the Canary Islands, the so-called "Basal Complex" visible on three islands, Fuerteventura (Stillman et al., 1975), Gomera (Cendrero, 1970) and La Palma (Hernández Pacheco, 1973), is essentially formed by intrusive complexes and dikes and has been interpreted as the roots of large volcanic complexes (Ancochea et al., 1996).

In the case of Lanzarote, gravity modelling shows three of those intrusive complexes with high density anomalies: the central one, a south-west one and finally one located off the north-eastern shore of Lanzarote, which could correspond to volcanic complexes.

A) San Bartolomé high density complex and San Bartolomé Volcanic Complex

The main density anomaly, SB, is located (Fig. 7) close to the village of San Bartolomé $\left(28^{\circ} 57^{\prime}, 13^{\circ} 39^{\prime}\right)$. The extension of the high Bouguer 


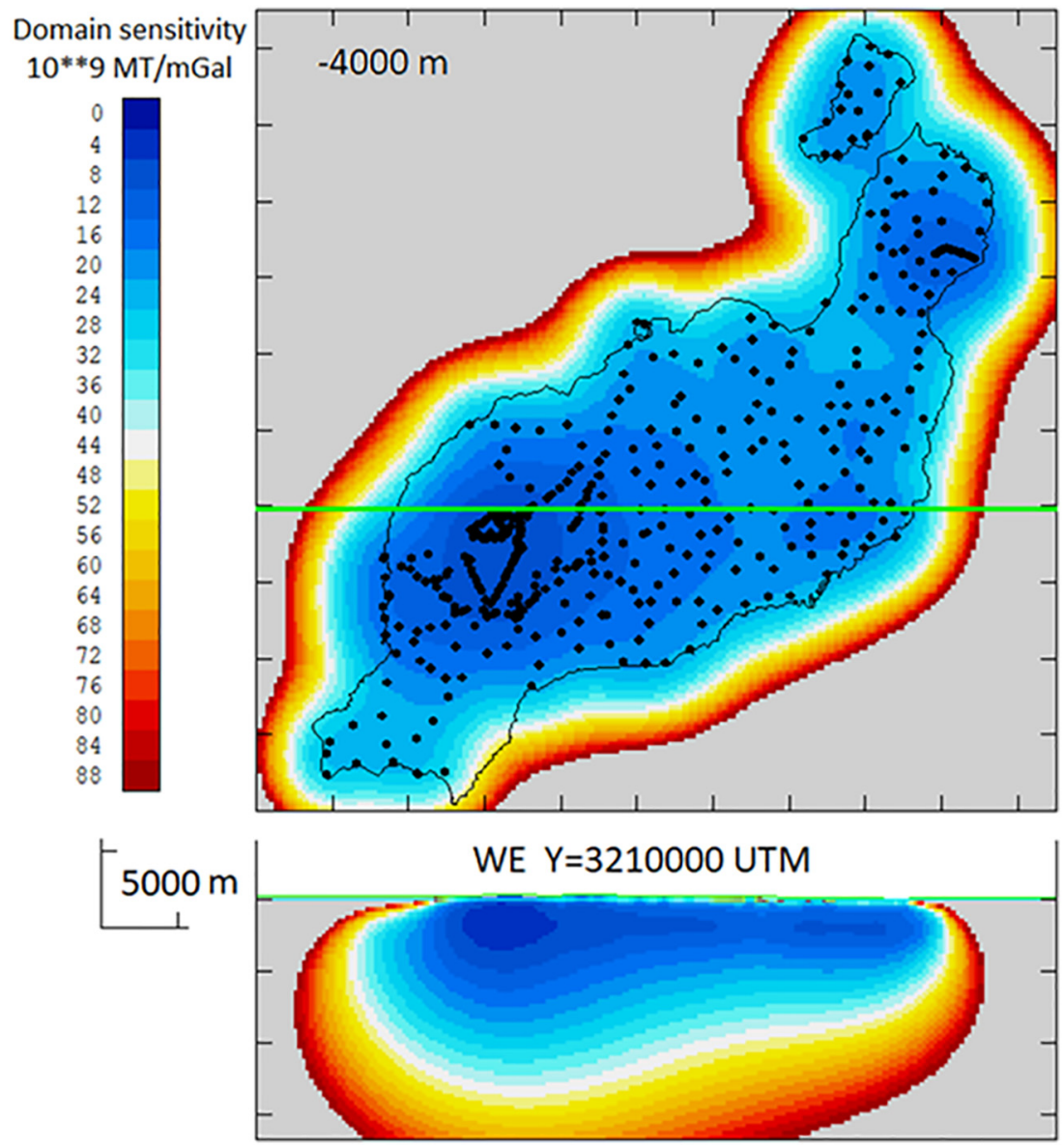

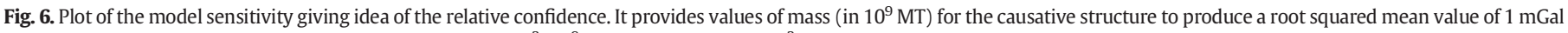

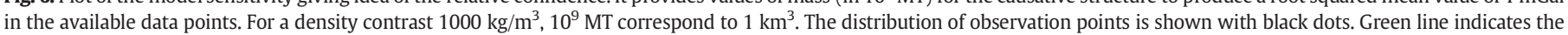
position of the vertical section shown below.

anomaly, and hence the responsible complex, is fully covered by our gravity survey. It shows a well-defined column-like geometry, with the top close to the terrain surface, and $>10 \mathrm{~km}$ deep. Its averaged horizontal diameter is around $15 \mathrm{~km}$ (see Fig. 7).

The SB body (Figs. 7 and 8) constitutes a remarkable and concentrated body with a very high anomalous mass beneath Lanzarote. Its total anomalous mass can be estimated as $6.4 \times 10^{14} \mathrm{~kg}$. Taking into account the resulting density contrast required by the gravity modelling (maximum density contrast about $550 \mathrm{~kg} / \mathrm{m}^{3}$ ), we can assume high density values (about $2900 \mathrm{~kg} / \mathrm{m}^{3}$ ) for the SB body core.

At mid-crustal depth ( 5 and $7 \mathrm{~km}$, for instance) the horizontal section of the SB body seems to offer a rounded triangular shape, with small elongations following $\mathrm{N} 25^{\circ} \mathrm{E}, \mathrm{N} 170^{\circ} \mathrm{E}$ and $\mathrm{N} 244^{\circ} \mathrm{E}$ directions (Fig. 7). This may suggest that repeated intrusion of dikes may cause the initiation of the rift zones. Conversely, horizontal tensional stresses in the (triple) fractures and increasing anisotropy would allow preferential emplacement of dikes at the rifts (Carracedo, 1999).

It is surprising that an intrusive structure, so well defined and of such magnitude as those that arise through "Basal Complexes" in Fuerteventura (Montesinos et al., 2005) and La Palma (Camacho et al., 2009), does not have the geologic and morphologic evidence which can be seen in the other islands and does not correspond to a large volcanic edifice or Volcanic Complex.

Actually, the area of the SB complex has a characteristic flat truncated conic shape with a mean elevation of about $200 \mathrm{~m}$, which includes many isolated, quaternary age (Pleistocene or Holocene) volcanic cones, and whose lava flows cover most of the area. There is no topographic (or even geologic) evidence of a large volcanic complex in this area. However, geology identifies some remaining unresolved, Miocene flow volcanic outcrop structures in the center of the island (Fig. 1b and c). They arise mainly from the outskirts of Arrecife to Tías and further west towards Uga and all of them are consistent with a Miocene age source ("Central volcanic Complex" in Fig. 1c). According to Fig. 9, our modelling shows that these volcanic outcrop structures, located close to Tias Village, (labelled as TI in Fig. 9) are connected to the main SB complex by shallow intrusive alignments.

The outcrops of Miocene lava flows from the center of the island indicate that there must have been a volcanic edifice in the area (the Central Volcanic Complex or San Bartolomé Volcanic Complex, SBVC). The South inclination of these lava flows indicates that they originated to the $\mathrm{N}$, where the center of the volcanic edifice would have been located. The outcrop alignment (NNE-SSW, Fig. 1b), similar to that of the more recent emission centers, could indicate that this edifice was fissural and elongated in that direction.

However, the bathymetry of the SE sector of the island, Fig. 1b, shows a very marked marine platform, with a curved plan, about $3 \mathrm{~km}$ wide and $<200$ m deep, which then descends sharply to an ocean floor at about $1500 \mathrm{~m}$ depth maintaining that curved morphology and where the gravity anomaly (see Fig. 7) is also located. This bathymetry is consistent with that of a circular volcanic edifice whose coastline would have been pushed back by sea erosion when its activity ceased.

This erosive platform exists in many of the Canary Islands large volcanic edifices (Llanes et al., 2009; Menard, 1983) and the older the edifice, the larger it is. In this case, it is as wide as upper Miocene age edifices, such as the Anaga or Teno edifices in Tenerife, and much narrower than Middle Miocene age edifices like Gran Canaria, and therefore consistent with being the erosive platform of this edifice in which ages of 6-7 Ma have been obtained (Coello et al., 1992). The 

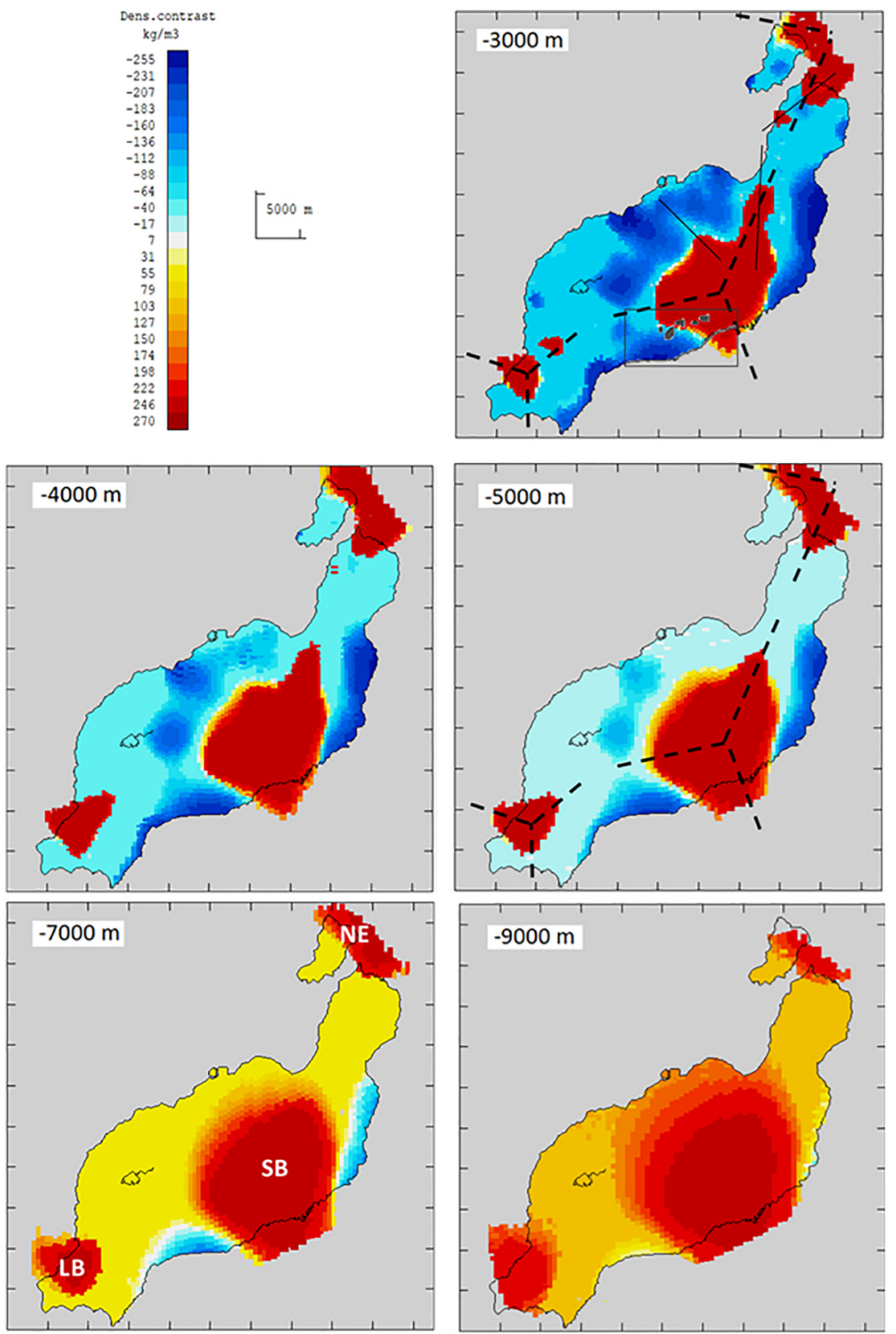

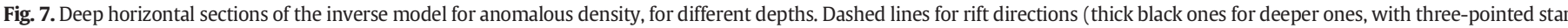

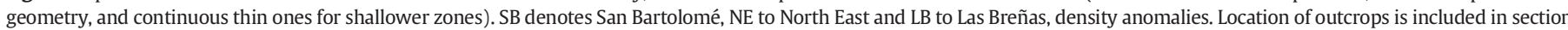
$-3000 \mathrm{~m}$.

possible general circular morphology of the SBVC is not incompatible with the three-pointed star structure shown by the gravity model (Fig. 7). On the contrary, in these large circular edifices there are often three preferential zones of intrusion (e.g., Carracedo, 1994). The outcrops between Arrecife and Tias would have been formed on the SW branch of that star.

With the existing data and model results, we can suppose that the SBVC would be a circular volcanic edifice with activity concentrated in three branches, and the center might be located in the area where these three branches meet, in the zone of the major gravity model positive anomaly (Fig. 10).

The absence of dikes or intrusive bodies in the outcrops of this SBVC indicates that the edifice would be scarcely eroded, because its roots are not visible, so it should cannot have been much higher than the current outcrops (200 m). If we keep the slopes observed in the lava flows, the SBVC could be approximately $500 \mathrm{~m}$ in the center.
As far as age goes, little can be known given the few existing outcrops. These are 6-7 Ma old (Coello et al., 1992), but may correspond only to a younger part of the SBVC, which is much older. Data from a deep sounding (Sánchez Guzmán and Abad, 1986), located in Timanfaya, far from the central part of the SBVC, and in an area where there are no notable magnetic anomalies (and therefore no important volcanic complex either), suggest that over the oceanic basement, from a depth of $2598 \mathrm{~m}$, are piles of submarine volcanic rocks (pillow-lavas and hyaloclastites) that have built up on the sea beds since the Mid Oligocene (35-28 million years ago). We cannot rule out that these volcanic rocks come from the SBVC, meaning that this dates back a very long time and therefore has a surely much more complex history. In this regard, it cannot be discarded that SBVC has older roots, even dating back to the Upper Cretaceous age, as Blanco-Montenegro et al. (2005) propose from paleomagnetic data. The importance of the SBVC gravity anomaly may to 

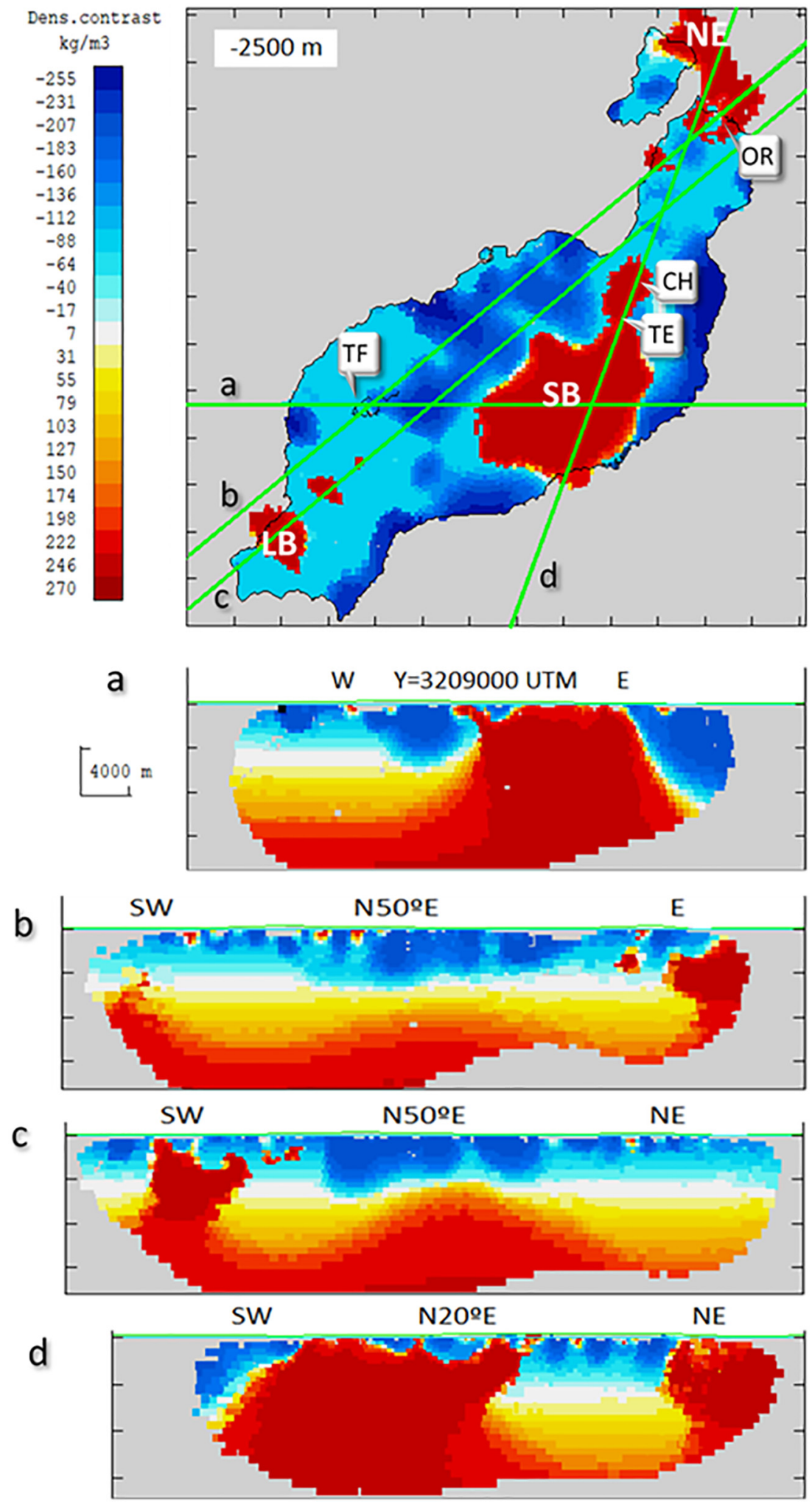

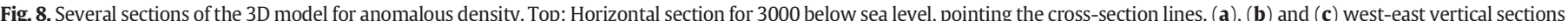

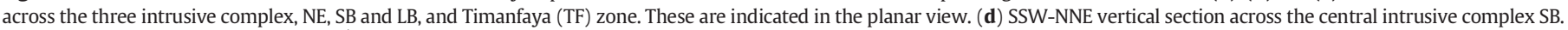
TE: Teguise; $\mathrm{CH}$ : Peñas del Chache, OR: Órzola.

some extent reflect that it has been an area of magma rise for many millions of years.

For the inland shallow lows, we observe some interesting alignments that follow roughly radial paths (N120E-N130E and N170E) close to Mozaga village (MO), above the SB body (Fig. 9). We propose two possible interpretations for the low density areas close to the SB complex:

(1) A lot of them looks to be clearly correlated with the location of quaternary volcanoes; this may be the case of the low density 

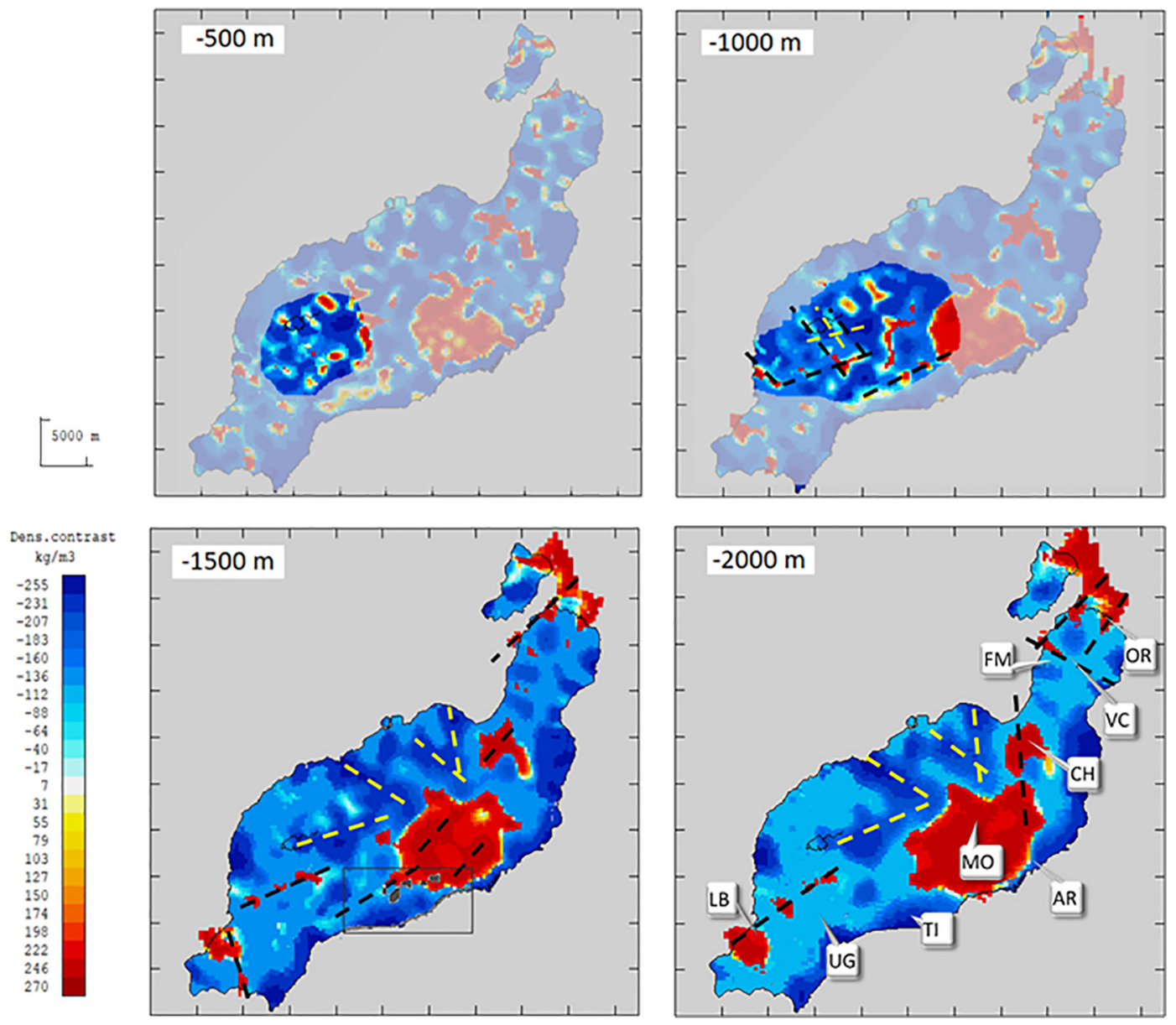

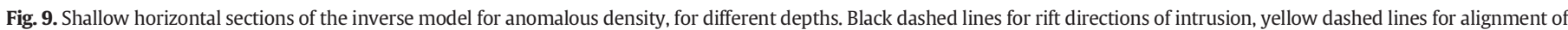

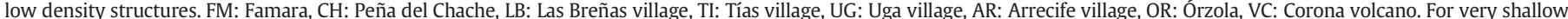

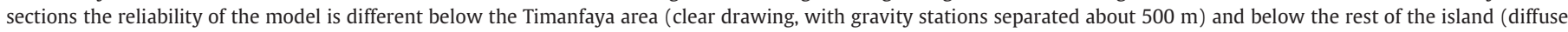
drawing, with gravity stations separated about $2 \mathrm{~km}$ ). Location of outcrops is included for section $-1500 \mathrm{~m}$.

areas located at W y NW del SB high density complex (ver Fig. 11). Therefore, they could be considered to be partially due to the accumulation of pyroclastic products.

(2) Another option we could propose is that most of them could be due to light sedimentary materials. This may be the cause of the areas of low density located at the N of the SB high density complex, which coincide with the area of accumulation of thicknesses of wind sands and dune fields (IGME, 2005).

These structures are located in the top of the sensitive volume of the model, taking into account the benchmark step (about $500 \mathrm{~m}$ for the Timanfaya area, and about $2 \mathrm{~km}$ for the rest of the island) (see Fig. 9 and Section 3). They have played an interesting role, as we will see below, allowing and guiding quaternary volcanism.

B) North-East high density complex and the Famara Volcanic Complex

The observed density anomaly suggests the existence of another main intrusive complex submerged in the NE offshore (approx. $29^{\circ} 18^{\prime}, 13^{\circ} 22^{\prime}$ ) (see Fig. 7). It would include an anomalous mass of about $2.7 \times 10^{14} \mathrm{~kg}$, more than half of the mass of intrusive complex SB. In spite of the partially extrapolation character of this NE structure, we can accept that it would have a similar structure and evolution as the complex SB (one closed deep magmatic source and a branching for the shallower areas).

The bathymetry of the northern part of Lanzarote Island (Fig. 1) reflects the existence of a very important submarine relief, of which only a small part is currently emerging: the Famara massif and the small islands of the Chinijo archipelago. Most of it is $<200 \mathrm{~m}$ deep and extends towards the NE, in the general direction of the Eastern Canarian dorsal. In that context, the FVC would only represent a part of that structure. The Chinijo archipelago and all the eastern part of the massif of Famara are formed by materials of Pleistocene or Holocene eruptions. The outcrops of the oldest rocks are restricted to the western zone and especially to the Famara cliff, which is where the best cross-sections of the FVC can be observed. The radiometric ages (Coello et al., 1992) suggest that this volcanic edifice has had a complex history, lasting at least from $10 \mathrm{Ma}$ and with significant pauses (over a million years) between growth phases and other ones. The Famara cliff, $>600 \mathrm{~m}$ in altitude and with a dip to the $\mathrm{E}$ of the materials that form it, indicates that a good part of that volcanic edifice has disappeared. All the area of origin of those lava flows, which should be located to the $\mathrm{W}$ and are at $>600 \mathrm{~m}$ in altitude, no longer exists. The linearity and homogeneity of the cliff are characteristic of a great slide towards the $\mathrm{W}$, which made more than half of the edifice disappear, as already proposed by Coello et al. (1992) and which are so prevalent throughout the archipelago (e.g., Krastel et al., 2001).

From the direction and inclination of the lava flows from the FVC and the direction of the dikes passing through it, we can deduce the 


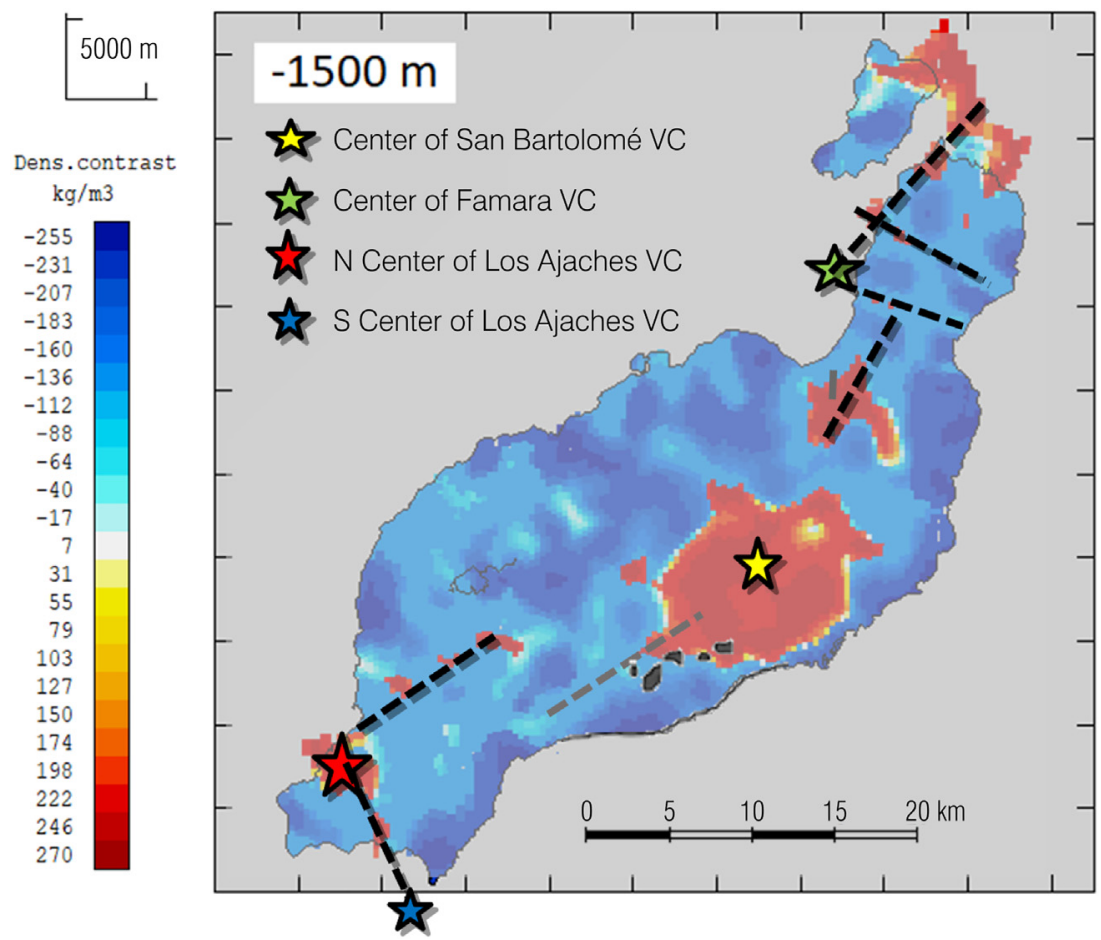

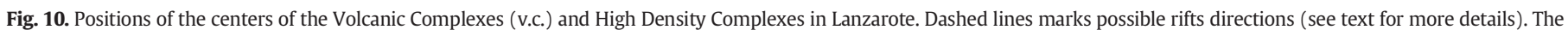
location of the outcrops associated with the central volcanic complex is included.

approximate position of its center (Fig. 10). A volcanic edifice with the center at that point would justify the geometry of the Famara materials, but not the presence of the NE density anomaly. This anomaly would reflect the existence of the rest of the submarine relief located to the NE.

The more noticeable feature of the NE high density complex is a NE$\mathrm{SW}$ branch, which leaves the main edifice at a depth $\sim 4 \mathrm{~km}$, close to
Órzola village (OR), following a gentle sloping path for about $10 \mathrm{~km}$, with a N50 ${ }^{\circ} \mathrm{E}$ direction (see Figs. 10 and 11 ). The elongated volcanic edifice corresponds to this magmatic branch which is partially visible today and would feed the FVC.

The very shallow sections of the 3D model for anomalous density (see section for $-1500 \mathrm{~m}$ in Fig. 9) show a rather gridded pattern of

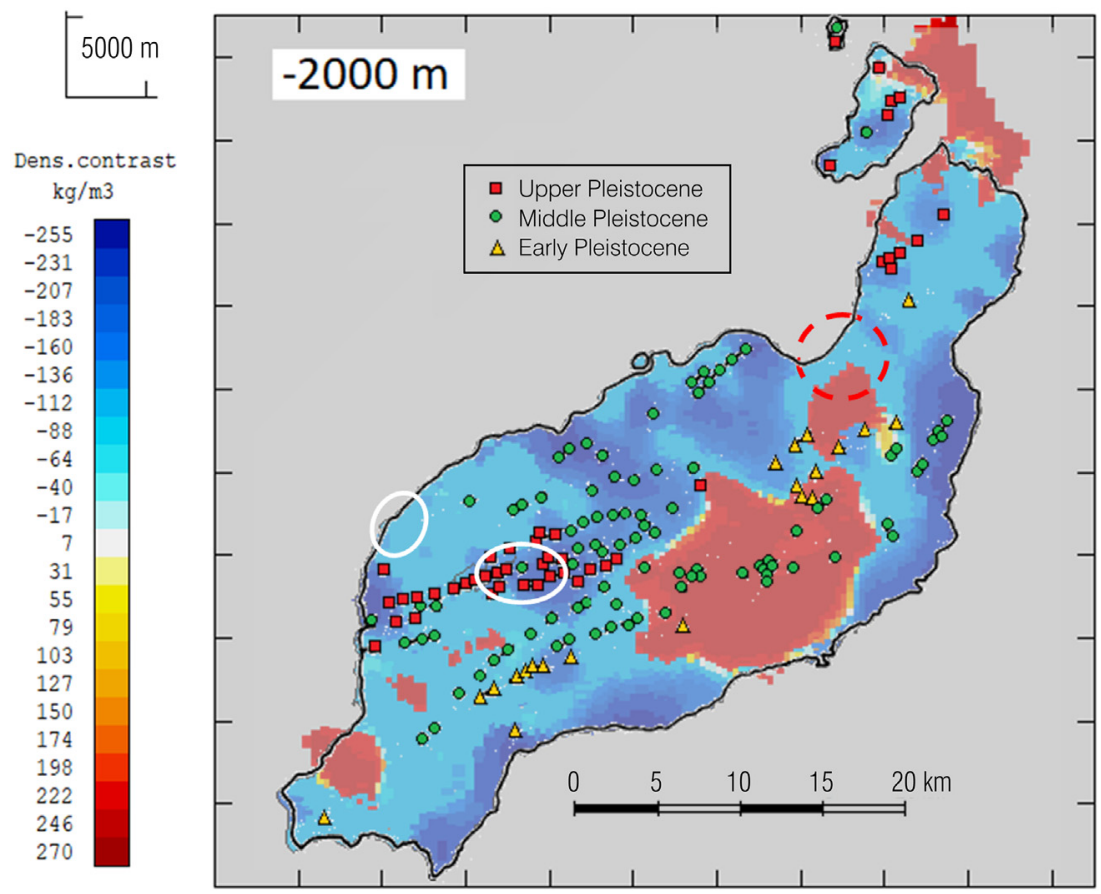

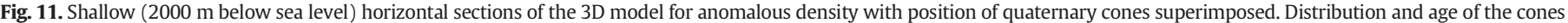

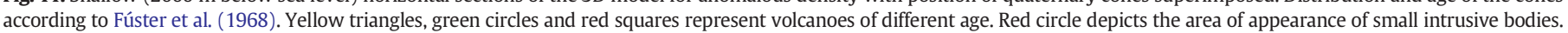
White ellipses depict the location of the deformations detected using advanced InSAR (González and Fernández, 2011). 
the intrusive high density structure. Main course is $\mathrm{N} 50^{\circ} \mathrm{E}$, and secondary course is nearly orthogonal. This gridded structure suggests the morphology of the ancient Famara relief. It is interesting to note the presence of a crossing knot of main and secondary lines, located in the sea near the west coast (Fig. 9) where Coello et al. (1992) locate the center of the Famara volcanic edifice.

The FVC could also be fed, in its southern part, by the SBVC whose NE branch almost joins the branch coming from the NE complex (see Figs. 1b and 10). The profusion of basic intrusions into SW of FVC are evidence of that possible feeding (Fig. 11).

C) South-west high density complex (Las Breñas) and the Ajaches Volcanic Complex

The inverse model presents a third intrusive body beneath Lanzarote Island. It is located at $\left(28^{\circ} 54^{\prime}, 13^{\circ} 50^{\prime}\right)$, close to Las Breñas village (LB in Fig. 9), and is mostly covered by our last gravity survey. It is clearly

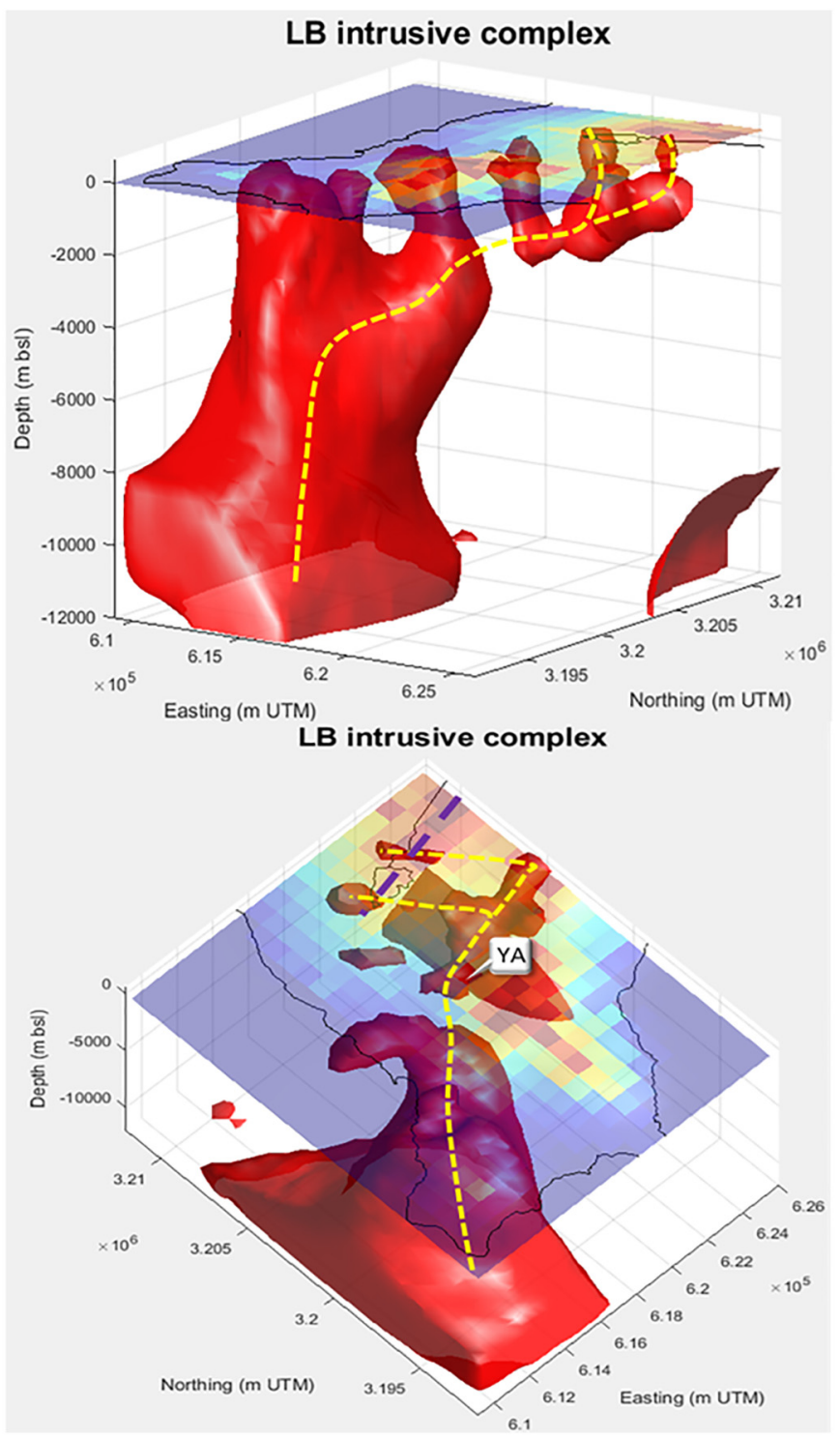

Fig. 12. Two 3D views of the model for the anomalous mass corresponding to the intrusive LB complex, showing the complete path (indicated by a yellow dashed line) for magmatic sources arriving in the Timanfaya area. It shows the limiting surface corresponding to an anomalous density contrast of $50 \mathrm{~kg} / \mathrm{m}^{3}$. Purple dashed line corresponds to the lowdensity alignment below Timanfaya area, deeper and probably older, see Fig. 4. YA: Yaiza village. much smaller than the SB body: deep ( $7 \mathrm{~km}$ ) horizontal diameter $\sim 5 \mathrm{~km}$; total anomalous mass $\sim 0.8 \times 10^{14} \mathrm{~kg}$ (about 8 times smaller than SB body). Nevertheless, there are similar morphological aspects. Apart from its size, the most relevant aspect of the LB body is its shape (Figs. 7, 8, 9 and 12). It is constituted by: (1) a thin like vertical cylinder, which nearly reaches the terrain level with a shallow horizontal diameter $\sim 3.5 \mathrm{~km}$, (2) a notable sub-horizontal branch that leaves the vertical body at a depth $\sim 4 \mathrm{~km}$ with a NE course of azimuth $\mathrm{N} 50^{\circ} \mathrm{E}$, and (3) a smaller branch that, at similar depths, leaves the vertical body with a SE (about $\mathrm{N} 140^{\circ} \mathrm{E}$ ) direction.

Broadly coinciding with the density anomaly are the remains of the Los Ajaches volcanic complex (AVC). This volcanic edifice, with a maximum elevation of $560 \mathrm{~m}$, was built in the Miocene between 16 and $12 \mathrm{Ma}$ (Coello et al., 1992; Ibarrola et al., 1988). Ancochea et al. (1996) inferred that Los Ajaches complex was originally 1.1-1.4 km high, surely centred below the vertical LB cylinder. The AVC dikes seem to come from two different volcanic centers. The older ones (which pass through the older materials of the AVC) seem to come from a volcanic center located in the sea, South of the island (S center, Fig. 10), while the younger dikes would belong to a volcanic center located further north ( $\mathrm{N}$ center, Fig. 10).

In this case, the gravity and geologic data correspond well. The deepest source has been located every time below Las Breñas, in a position similar to the $\mathrm{N}$ volcanic center (Fig. 9), which is the main center of the Ajaches Volcanic Complex (Ancochea et al., 1996). In contrast, the southernmost volcanic center does not correspond to a gravity anomaly, but would be connected to the continuation of the SE intrusive branch (about $\mathrm{N} 140^{\circ} \mathrm{E}$ ) in the sea (Fig. 10).

There is an interesting peculiarity: the striking alignment $\left(\sim \mathrm{N} 47^{\circ} \mathrm{E}\right)$ between the main NE branch of the LB complex and the SW subhorizontal branch of the NE complex (Figs. 8 and 10). It suggests a geodynamic connection between the genesis of both structures by means a common rift direction, perhaps, reflecting a major structure related to the Fuerteventura-Lanzarote-Banco de la Concepción lineament (East Canary Islands Ridge, Fig. 1).

D) Timanfaya

The higher data resolution in this LB area and within the Timanfaya area provides additional details about the high density conduit-branch. Fig. 12 shows the conduit-branch obtained with a limiting surface corresponding to an anomalous density contrast of $50 \mathrm{~kg} / \mathrm{m}^{3}$. Our density distribution suggests a plumbing path (yellow dashed line in Fig. 12) by which magma reached the Timanfaya volcanic area. The steps could be as follows:

(a) It seems to start in the only deep source in this zone: the LB body. It could depart from the deepest zones and follow a nearly vertical path close to the cylinder contour, or it could start from a preserved magma reservoir close to the cylinder contour, at a depth of about $4 \mathrm{~km}$ (zone of branching and probably vertical discontinuity). It would be consistent with the results by González et al. (2013) for the last eruption in El Hierro Island in 2011-2012.

(b) Then, it would move $\mathrm{N} 50^{\circ} \mathrm{E}$ close to the existing main branch (corresponding to a weakness path), within a sub-horizontal slightly upward path of about $12 \mathrm{~km}$.

(c) Afterwards, it would reach a probably secondary and shallower reservoir located close to Yaiza village (labelled as YA in Fig. 12), perhaps $1.5 \mathrm{~km}$ deep, just in the cross knot of the main NE branch with a lateral NW weakness course.

(d) Then it follows the definitive sub-horizontal path with NW course, about $4 \mathrm{~km}$ in a secondary branch. The magma did not emerge on the surface due to the low energy (low buoyancy). 
(e) However, the magma path suddenly crosses pre-existing, very low density lines: those ENE and ESE located westward from the central SB complex (yellow dashed line in Fig. 12). This circumstance would result in the creation of many volcanic vents open along the ENE ESE lines and low density (Fig. 11).

The Timanfaya eruption cannot have been the sole source of the gravity anomalies, and the gravity model presented includes not only the Timanfaya eruption, but also the rest of subparallel Pleistocene eruptions (including the failed ones). Indeed, this magma ascent path, valid for the Timanfaya eruption, may have also served for the magma ascent of the volcanic alignments subparallel to the Timanfaya eruption that took place throughout the Pleistocene (e.g., Galindo et al., 2016 or Fig. 11), with, overall, a much higher volume than Timanfaya.

The NE-SW direction, the main direction that joins the Fuerteventura structures with Ajaches, appears in the LB intrusive complex and changes, in that zone, to a ENE-WNW direction [Ancochea et al., 1996, Fig. 8], following a pattern that runs sub-parallel to that of the nearby African coast. Moreover, there is an "anomalous" topography in that part of the island. In that central-western area of the island there is no evidence of the existence of a Miocene structure and it would be an underwater area today, if it were not for the Pleistocene eruptions that joined the Miocene structures of Ajaches and San Bartolomé in a single island.

The Timanfaya area was where the last volcanic activity took place in Lanzarote $(1730-1736,1824)$, but some deformation is also currently taking place in this area. It would be interesting to know if there is some correspondence between the deformation areas and density structure we have obtained. González and Fernández (2011) applied a multitemporal error estimation method for Interferometric Synthetic Aperture Radar (InSAR) processing to measure crustal deformation in Lanzarote Island (Canary Islands) during the period 1992-2000. They detected displacements around Timanfaya volcano which were considered subsidence, and closely follow the surface temperature anomalies, indicating that the magmatic body under Timanfaya volcano is still crystallizing. They show that most of the area of Lanzarote is stable at the level of about $\pm 1 \mathrm{~mm} /$ year. The largest deformation rates are associated to the Timanfaya eruption area (Montañas del Fuego) with linear velocities of 4-6 mm/year, affecting an area of approximately $7 \mathrm{~km}^{2}$. The second deformation area presents linear velocities of around 3-4 mm/year and is located on the north western coast (see our Fig. 11 and the Fig. 8 by González and Fernández (2011)). Displacement measurements show a spatial continuity and a possible connection between both deformation areas and possible origins (González and Fernández, 2011). Maximum deformation is located at Islote de Hilario and Hoya de los Camelleros area (IH and $\mathrm{HC}$ respectively in Fig. 2), in the easternmost NW-SE trending subsidence. This deformation has been confirmed recently by Riccardi et al. (2018) using GNSS, tiltmeter and strainmeter records. González and Fernández (2011) propose that this deformation is caused by an existing ancient thermally contracting shallow magma reservoir. This should agree with previous studies which proposed a partly molten magmatic chamber underneath Timanfaya area, at approximately $4 \mathrm{~km}$ depth (Araña et al., 1984; Ortíz et al., 1986).

We do not find evidence of any magma chamber below Timanfaya as proposed by previous works. Lodge et al. (2012) also found no evidence for a low velocity zone corresponding to partial melt. Therefore we conclude that if it exists, it should have a density similar to the surrounding media. Like Camacho et al. (2001), we just find negative anomalies around $2 \mathrm{~km}$ depth in that area. Nor do we find any density anomaly associated with the deformation area close to the beach, see Fig. 10, but we have no data in that area (Fig. 2b). According to our modelling, in Lanzarote there are only three deep magma sources SB, NE and LB, and possible magma chambers would be connected with the proposed structure by some lateral branching.

\section{Conclusions}

We have used gravity data and an improved nearly automatic inversion methodology to fit a subsurface structure for anomalous density distribution corresponding to the observed gravity anomaly for Lanzarote Island. It allowed us to obtain some 3-D bodies of high and low density immersed in a multi-layered medium with downward density increase.

In Lanzarote there are three intrusive (high density) sources: the main central SB complex $\left(28^{\circ} 57^{\prime}, 13^{\circ} 39^{\prime}\right)$, a complex below the sea in the NE offshore, and the third one, the South-West LB complex $\left(28^{\circ} 54^{\prime}, 13^{\circ} 50^{\prime}\right)$. The size and shape of these complexes are different, mostly depending on the magnitude of the magma supply and on its time evolution (aging, and rest and reactivation phases). The three sources of magma intrusion (Fig. 10) coincide with the areas where the oldest volcanic materials (Miocene) appear (Fig. 1). However, there are clear differences between them. Both the magnitude of the anomalies (SB: $6.4 \times 10^{14} \mathrm{~kg}, \mathrm{NE}: 2.7 \times 10^{14} \mathrm{~kg}$, and LB: 0.80 $\times 10^{14} \mathrm{~kg}$ ) and the correspondence with the volcanic reliefs are totally different.

The SB high density complex, which is the most important, does not correspond to a significant subaerial volcanic edifice. However, the Miocene age outcrops that exist in that area and which, so far, had no easy explanation, can now be interpreted as the remains of a low volcanic subaerial edifice, with a circular tendency and with three developed rift branches, whose center coincides with the position of the gravity anomaly. The submarine materials that appeared in the Timanfaya deep sounding could belong to a great volcanic complex (the San Bartolomé Volcanic Complex, SBVC), that was already active in the middle Oligocene. The volcanic activity in Lanzarote could thus begin in the SBVC.

The SB complex has a north-eastward rift branch (course from $\mathrm{N} 20^{\circ} \mathrm{E}$ in the bottom to nearly reach the $\mathrm{SN}$ direction for its shallowest part) constituting the present Peñas del Chache mountains, which continue the Famara massif. In spite of the morphological union with the Famara complex, gravity results show a clear different genesis, from different and very far intrusive complexes.

The NE high density complex is essentially submerged and the center of the main subaerial volcanic edifice of the area (the FVC) is located about $10 \mathrm{~km} \mathrm{SW}$ of it (Fig. 9). It has a large (about $10 \mathrm{~km}$ ) SE rift branch (course $50^{\circ} \mathrm{N}$ ) which surely fed the FVC, and it is cut by a NE-SW fault leading to the impressive cliffs of Famara. Even this fissural plumbing system resulted in a sub-historical eruption (Corona Volcano). For shallower levels, Famara intrusive complex appears with grid morphology, with a crossing knot located in the west offshore where it the FVC center should be located.

The SW intrusive complex is the one that best matches the volcanic sub-air edifices and its center coincides with the center of the Ajaches Volcanic Complex (AVC). The volcanic activity in the AVC would have migrated from an older center, located in the sea, to the south of the island. One arm of the anomaly (direction $\mathrm{N} 140^{\circ}$ ) reflects the migration path between the two volcanic centers.

Finally, nearly half the LB complex is formed by a north-eastern branch (course $50^{\circ} \mathrm{N}$ ), pointing towards Yaiza (YA in Fig. 11). A steeply sloping sub-branch that crosses the Timanfaya area with a SE-NW course fed the Pleistocene eruptions and even the Timanfaya eruption. The shallow sections also show a grid pattern for the intrusive structures and the global modelling lets us propose a 3D complete plumbing path for Timanfaya eruptions.

In summary, for Lanzarote four different cases of correlation between gravity anomalies and large volcanic structures can be observed. As usual (see e.g., Montesinos et al., 2005; Flinders et al., 2010; Represas et al., 2012) the SW intrusive complex presents a good match between the gravity anomaly and the position of a large central volcanic structure (Ajaches). But other different, more infrequent cases are also to be found on the island. In the SB complex, gravimetry indicates the 
existence of another large central volcanic structure that, however, is not reflected significantly in morphological terms. For the NE anomaly there is no precise correspondence between gravimetry and the position of the visible central volcanic edifice (Famara), which would be fed from other areas. While the Quaternary volcanic activity, of a fissural nature, does not give rise to an anomaly centred on the area, but seems to be connected to the SW feeding area of the island. All these results allow us to reconstruct a far more complex volcanological history of Lanzarote and will help to build a new model of its evolution.

\section{Acknowledgments and data}

This research has been supported through the MINECO research projects AYA2010-17448, ESP2013-47780-C2-1-R, CGL2017-86241-R, PR41/17-20952 and the CSIC project 201530E019.The survey work carried out in 2012 in Timanfaya was made possible by the facilities provided by the authorities of Timanfaya National Park. We thank V. Acocella and an anonymous reviewer for their useful comments on a previous version of this manuscript.

Gravity data used to obtain the anomaly map inverted to get the 3D density model (Camacho et al., 2017) (http://dx.doi.org/10.20350/ digitalCSIC/8509) can be obtained asking to the corresponding author or at http://hdl.handle.net/10261/153762.

\section{Declaration of interest}

None.

\section{References}

Abdel-Monem, A., Watkins, N.D., Gast, P.W., 1971. Potassium-argon ages, volcanic stratigraphy, and geomagnetic polarity history of the Canary Islands: Tenerife, La Palma, and Hierro. Am. J. Sci. 272, 805-825. https://doi.org/10.2475/ajs.272.9.805.

Ancochea, E., Brändle, J.L., Cubas, C.R., Hernán, F., Huertas, M.J., 1996. Volcanic complexes in the eastern ridge of the Canary Islands: the Miocene activity of the island of Fuerteventura. J. Volcanol. Geotherm. Res. 70, 183-204. https://doi.org/10.1016/ 0377-0273(95)00051-8.

Ancochea, E., Brändle, J.L., Huertas, M.J., Cubas, C.R., Hernán, F., 2003. The felsic dikes of La Gomera (Canary Islands): identification of cone sheet and radial dike swarms. J. Volcanol. Geotherm. Res. 120, 197-206. https://doi.org/10.1016/S0377-0273(02) 00384-0.

Ancochea, E., Brändle, J.L., Huertas, M.J., Hernán, F., Herrera, R., 2008. Dike-swarms, key to the reconstruction of major volcanic edifices: the basic dikes of La Gomera (Canary Islands). J. Volcanol. Geotherm. Res. 173, 207-216. https://doi.org/10.1016/j. jvolgeores.2008.01.020

Anguita, F., Hernán, F., 1975. A propagating fracture model versus a hot spot origin for the Canary Islands. Earth Planet. Sci. Lett. 27, 11-19. https://doi.org/10.1016/0012-821X (75)90155-7.

Anguita, F., Hernán, F., 2000. The Canary Islands origin: a unifying model. J. Volcanol. Geotherm. Res. 103 (1-4), 1-26. https://doi.org/10.1016/S0377-0273(00)00195-5.

Araña, V., Díez, J., Ortíz, R., Yuguero, J., 1984. Convection of geothermalfluids in the Timanfaya volcanic area (Lanzarote, Canary Islands). Bull. Volcanol. 47 (3), 667-677. https://doi.org/10.1007/BF01961234.

Armenti, P., Marinoni, L., Pasquare, G., 1989. Geological map of the island of Lanzarote. ESF Meeting on Canarian Volcanism, Lanzarote, 198-200. European Science Foundation, Madrid, Spain.

Banda, E., Dañobeitia, J.J., Suriñach, E., Ansorge, J., 1981. Features of crustal structure under Canary Islands. Earth Planet. Sci. Lett. 55, 11-24. https://doi.org/10.1016/0012-821X (81)90082-0.

Blanco-Montenegro, I., Montesinos, F.G., García, A., Vieira, R., Villalaín, J.J., 2005. Paleomagnetic determinations on Lanzarote from magnetic and gravity anomalies: implications for the early history of the Canary Islands. J. Geophys. Res. 110, B12102. https://doi.org/10.1029/2005JB003668.

BODC, 2014. The GEBCO_2014 Grid, Version 20150318. Data Base. Published on Behalf of the Intergovernmental Oceanographic Commission and the International Hydrographic Organization as Part of the General Bathymetric Chart of the Oceans. British Oceanographic Data Centre, Liverpool, UK.

Camacho, A.G., Montesinos, F.G., Vieira, R., 2000. A 3-D gravity inversion by means of growing bodies. Geophysics 65, 95-101. https://doi.org/10.1190/1.1444729.

Camacho, A.G., Montesinos, F.G., Vieira, R., Arnoso, J., 2001. Modelling of crustal anomalies for Lanzarote (Canary Islands) in light of gravity. Geophys. J. Int. 147, 403-414. https://doi.org/10.1046/j.0956-540x.2001.01546.x.

Camacho, A.G., Montesinos, F.G., Vieira, R., 2002. A 3-D gravity inversion tool based on exploration of model possibilities. Comput. Geosci. 28, 191-204. https://doi.org/ 10.1016/S0098-3004(01)00039-5.

Camacho, A.G., Nunes, J.C., Ortíz, E., França, Z., Vieira, R., 2007. Gravimetric determination of an intrusive complex under the island of Faial (Azores): some methodological improvements. Geophys. J. Int. 171, 478-494. https://doi.org/10.1111/j.1365246X.2007.03539.x.

Camacho, A.G., Fernández, J., González, P.J., Rundle, J.B., Prieto, J.F., Arjona, A., 2009. Structural results for La Palma Island using 3-D gravity inversion. J. Geophys. Res. 114, B05411. https://doi.org/10.1029/2008JB005628.

Camacho, A.G., Fernández, J., Gottsmann, J., 2011a. The 3-D gravity inversion package GROWTH2.0 and its application to Tenerife Island, Spain. Comput. Geosci. 37, 621-633. https://doi.org/10.1016/j.cageo.2010.12.003.

Camacho, A.G., Fernández, J., Gottsmann, J., 2011b. A new gravity inversion method for multiple subhorizontal discontinuity interfaces and shallow basins. J. Geophys. Res. 116, B02413. https://doi.org/10.1029/2010JB008023.

Camacho, A.G., Fernández, J., Vieira, R., Prieto, J.F., 2017. Lanzarote (Canary Islands) Observed Gravity Data (Datum GRS80). Dataset. http://dx.doi.org/10.20350/ digitalCSIC/8509 retrieved from. http://hdl.handle.net/10261/153762.

Carracedo, J.C., 1994. The Canary Islands: an example of structural control on the growth of large oceanic-island volcanoes. J. Volcanol. Geotherm. Res. 60 (3-4), 225-241. https://doi.org/10.1016/0377-0273(94)90053-1.

Carracedo, J.C., 1999. Growth, structure, instability and collapse of Canarian volcanoes and comparisons with Hawaiian volcanoes. J. Volcanol. Geotherm. Res. 94, 1-19. https:// doi.org/10.1016/S0377-0273(99)00095-5.

Cendrero, A., 1970. The volcano-plutonic complex of La Gomera, Canary Islands. Bull. Volcanol. 34, 537-561. https://doi.org/10.1007/BF02596770.

Coello, J., Cantagrel, J.M., Hernán, F., Fúster, J.M., Ibarrola, E., Ancochea, E., et al., 1992. Evolution of the eastern volcanic ridge of the Canary Islands based on new $\mathrm{K}-\mathrm{Ar}$ data. J. Volcanol. Geotherm. Res. 53 (1-4), 251-274. https://doi.org/10.1016/0377-0273 (92)90085-R.

Dañobeitia, J.J., 1988. Reconocimiento geofísico en el área del Archipiélago Canario. Rev. Soc. Geol. Esp. 1, 143-155.

del Potro, R., Díez, M., Blundy, J., Camacho, A.G., Gottsmann, J., 2013. Diapiric ascent of silicic magma beneath the Bolivian Altiplano. Geophys. Res. Lett. 40, 2044-2048. https://doi.org/10.1002/grl.50493.

Díez Gil, J.L., Yuguero, J., Ortíz, R., Araña, V., 1986. Termometrías y modelos matemáticos para el estudio de gradientes térmicos superficiales en Lanzarote (Islas Canarias). Anales de Física B 82, 91-101.

EMODnet Bathymetry Consortium, 2016. EMODnet Digital Bathymetry (DTM). https:// doi.org/10.12770/c7b53704-999d-4721-b1a3-04ec60c87238.

Fisher, R.V., Schmincke, H.U., 1984. Pyroclastic Rocks. Springer-Verlag (472 pp).

Flinders, A.F., Ito, G., García, M.O., 2010. Gravity anomalies of the Northern Hawaiian Islands: implications on the shield evolutions of Kauai and Niihau. J. Geophys. Res. 115, B08412. https://doi.org/10.1029/2009JB006877.

Fúster, J.M., Fernández Santín, S., Sagredo, J., 1968. Geología y Volcanología de las Islas Canarias: Lanzarote. Instituto "Lucas Mallada" - C.S.I.C, Madrid.

Galindo, I., Romero, M.C., Sánchez, N., Morales, J.M., 2016. Quantitative volcanic susceptibility analysis of Lanzarote and Chinijo Islands based on kernel density estimation via a linear diffusion process. Sci. Rep. 6 (27381). https://doi.org/ $10.1038 /$ srep 27381.

Geldmacher, J., Hoernle, K.A., van den Bogaard, P., Zankl, G., Garbe-Schönberg. D., 2001 Earlier history of the $>70$-Ma-old Canary hotspot based on the temporal and geochemical evolution of the Selvagen Archipelago and neighboring seamounts in the eastern North Atlantic. J. Volcanol. Geotherm. Res. 111, 55-87. https://doi.org/ 10.1016/S0377-0273(01)00220-7.

González, P.J., Fernández, J., 2011. Error estimation in multitemporal InSAR deformation time series, with application to Lanzarote, Canary Islands. J. Geophys. Res. 116 B10404. https://doi.org/10.1029/2011JB008412.

González, P.J., Samsonov, S.V., Pepe, S., Tiampo, K.F., Tizzani, P., Casu, F., Fernández, J. Camacho, A.G., Sansosti, E., 2013. Magma storage and migration associated with the 2011-2012 El Hierro eruption: implications for crustal magmatic systems at oceanic island volcanoes. J. Geophys. Res. Solid Earth 118, 4361-4377. https://doi.org/ 10.1002/jgrb.50289.

Gottsmann, J., Camacho, A.G., Marti, J., Wooller, L., Fernández, J., Garcia, A., Rymer, H. 2008. Shallow structure beneath the Central Volcanic Complex of Tenerife from new gravity data: implications for its evolution and recent reactivation. Phys. Earth Planet. Inter. 168, 212-230. https://doi.org/10.1016/j.pepi.2008.06.020.

Gripp, A.E., Gordon, R.G., 2002. Young tracks of hotspots and current plate velocities. Geophys. J. Int. 150, 321-361. https://doi.org/10.1046/j.1365246X.2002.01627.X.

Grunau, H.R., Lehner, P., Cleintuar, M.R., Allebanch, P., Bakker, G., 1975. New radiometric ages and seismic data from Fuerteventura (Canary Islands), Maio (Cape Verde Island) and Sao Tomé (Gulf of Guinea). In: Borradaile, G.J., et al. (Eds.), Progress in Geodynamics. R. Soc. Neth. Acad. Arts. Sci, Amsterdam, pp. 89-118.

Hansteen, T.H., Klügel, A. Schmincke, H.U., 1998. Multi-stage magma ascent beneath the Canary Islands: evidence from fluid inclusions. Contrib. Mineral. Petrol. 132, 48-64. https://doi.org/10.1007/s004100050404.

Hautmann, S., Camacho, A.G., Gottsmann, J., Odbert, H.M., 2013. The shallow structure beneath Montserrat (West Indies) from new Bouguer gravity data. Geophys. Res. Lett. 40, 5113-5118. https://doi.org/10.1002/grl.51003.

Hernández Pacheco, A., 1973. Sobre el significado de las rocas granudas gabroides de los complejos basales de las islas de Fuerteventura, La Palma y La Gomera, Archipiélago Canario. Estud. Geol. 29, 549-557.

Hoernle, K., Schmincke, H.U., 1993. The petrology of the tholeiites through melilitenephelinites on Gran Canaria, Canary Islands: crystal fractionation, accumulation, and depths of melting. J. Petrol. 34, 573-397. https://doi.org/10.1093/petrology/ 34.3.573.

Holik, J., Rabinowitz, P., Austin, J.A., 1991. Effects of canary hotspots volcanism on structure of oceanic crust of Morocco. J. Geophys. Res. 96, 12039-12067. https://doi.org 10.1029/91JB00709. 
Ibarrola, E., Cantagrel, J.M., Fúster, J.M., Coello, J., Jamond, C., 1988. Geocronología de las series volcánicas neógenas de Lanzarote (Islas Canarias). Paper Presented at II Congreso Geológico de España, Simposios. pp. 345-348 (Granada, Spain).

IGME, 2005. Mapa Geológico de España 1:100.000 (Hoja no 88, Lanzarote, 79 pp). Instituto Geológico y Minero de España, Madrid.

Krastel, S., Schmincke, H.U., Jacobs, C.L., Rihm, R., Le Bas, T.P., Alibés, B., 2001. Submarine landslides around the Canary Islands. J. Geophys. Res. 106, 3977-3997. https://doi. org/10.1029/2000JB900413.

Langenheim, V.A.M., Clague, D.A., 1987. The Hawaiian Emperor volcanic chain; part II. Stratigraphic framework of volcanic rocks of the Hawaiian Islands. In: Decker, R.W. et al. (Eds.), Volcanism in Hawai, USGS Professional. Paper 1350. 1. U.S. Geological Survey, Reston, VA, pp. 55-84. https://doi.org/10524/33605.

Le Bas, M.J., Rex, D.C., Stillman, C.J., 1986. The early magmatic chronology of Fuerteventura, Canary Islands. Geol. Mag. 123, 287-298. https://doi.org/10.1017/ S0016756800034762.

Leahy, G.M., Park, J., 2005. Hunting for oceanic island Moho. Geophys. J. Int. 160 1020-1026. https://doi.org/10.1111/j.1365-246X.2005.02562.x.

Lister, J.R., Kerr, R.C., 1991. Fluid-mechanical models of crack propagation and their application to magma transport in dykes. J. Geophys. Res. 96, 10049-10077. https://doi. org/10.1029/91JB00600.

Llanes, P., Herrera, R., Gómez, M., Muñoz, A., Acosta, J., Uchupi, E., Smith, D., 2009. Geological evolution of the volcanic island La Gomera, Canary Islands, from analysis of its geomorphology. Mar. Geol. 264 (3), 123-139. https://doi.org/10.1016/j. margeo.2009.05.001.

Lodge, A., Nippress, S.E.J., Rietbrock, A., García-Yeguas, A., Ibáñez, J., 2012. Evidence fo magmatic underplating and partial melt beneath the Canary Islands derived using teleseismic receiver functions. Phys. Earth Planet. Inter. 212-213, 44-54. https:// doi.org/10.1016/j.pepi.2012.09.004.

MacFarlane, D.J., Ridley, W.I., 1969. An interpretation of gravity data for Lanzarote, Canary Islands. Earth Planet. Sci. Lett. 6, 431-436. https://doi.org/10.1016/0012-821X(69) 90112-5.

Malengreau, B., Lénat, J.-F., Froger, J.-F., 1999. Structure of Réunion Island (Indian Ocean) inferred from the interpretation of gravity anomalies. J. Volcanol. Geotherm. Res. 88 131-146. https://doi.org/10.1016/S0377-0273(98)00114-0.

Martínez del Olmo, W., Buitrago Borrás, J., 2002. Sedimentary and volcanic record east of Lanzarote and Fuerteventura islands (Fúster Casas trough). Geogaceta 32, 51-54.

Menard, H., 1983. Insular erosion, isostasy, and subsidence. Science 220 (4600), 913-918. https://doi.org/10.1126/science.220.4600.913.

Montesinos, F.G., Arnoso, J., Vieira, R., 2005. Using a genetic algorithm for 3-D inversion of gravity data in Fuerteventura (Canary Islands). Int. J. Earth Sci. 94, 301-316. https:// doi.org/10.1007/s00531-005-0471-6.

Navarro, J.M., Farrujia, I., 1989. Plan hidrológico insular de Tenerife. Aspectos geológicos e hidrogeológicos. (145 pp). Dirección General de Aguas, Gobierno de Canarias, Tenerife, Spain.

Ortíz, R., Araña, V., Astiz, M., García, A., 1986. Magnetotelluric study of the Teide (Tenerife) and Timanfaya (Lanzarote) volcanic areas. J. Volcanol. Geotherm. Res. 30, 357-377. https://doi.org/10.1016/0377-0273(86)90061-2.

Represas, P., Catalao, J., Montesinos, F.G., Madeira, J., Mata, J., Antunes, C., Moreira, M., 2012. Constraints on the structure of Maio Island (Cape Verde) by a threedimensional gravity model: imaging partially exhumed magma chambers. Geophys. J. Int. 190, 931-940. https://doi.org/10.1111/j.1365-246X.2012.05536.X.
Riccardi, U., Arnoso, J., Benavent, M., Vélez, E., Tammaroe, U., Montesinos, F.G., 2018. Exploring deformation scenarios in Timanfaya volcanic area (Lanzarote, Canary Islands) from GNSS and ground based geodetic observations. J. Volcanol. Geotherm. Res. 357, 14-24. https://doi.org/10.1016/j.jvolgeores.2018.04.009.

Ryan, M.P., 1987. Magmatic processes: physiochemical principles. In: Mysen, B.O. (Ed.), Geochemical Society Special Publications Series 1. The Geochemical Society, Washington, DC, pp. 259-287.

Rymer, H. Brown, G.C. 1986. Gravity fields and the interpretation of volcanic structures: geological discrimination and temporal evolution. J. Volcanol. Geotherm. Res. 27, 229-254. https://doi.org/10.1016/0377-0273(86)90015-6.

Sánchez Guzmán, J., Abad, J., 1986. Sondeo geotérmico Lanzarote-1, Significado geológico y geotérmico. Anales de Física 82, 102-109.

Sandwell, D.T., Smith, W.H.F., 1997. Marine gravity anomaly from Geosat and ERS 1 satellite altimetry. J. Geophys. Res. 102 (B5), 10039-10054. https://doi.org/10.1029/ 96JB03223.

Schmincke, H.U., 1982. Volcanic and chemical evolution of the Canary Islands. In: von Rad, U., et al. (Eds.), Geology of the Northwest African Continental Margin. Springer, Berlin, Germany, pp. 273-301 https://doi.org/10.1007/978-3-642-68409-8_12.

Stillman, C.J., Fúster, J.M., Bennell Baker, M.J., Muñoz, M., Smewing, J.D., Sagredo, J., 1975. Basal complex of Fuerteventura is an oceanic intrusive complex with rift-system affinities. Nature 257, 469-470. https://doi.org/10.1038/257469a0.

Tarantola, A., 1988. Inverse Problem Theory. Methods for Data Fitting and Model Parameter Estimation. (630 pp). Elsevier, Amsterdam, The Netherlands.

Tiede, C., Camacho, A.G., Gerstenecker, C., Fernández, J., Suyanto, I., 2005. Modeling the density at Merapi volcano area, Indonesia, via the inverse gravimetric problem. Geochem. Geophys. Geosyst. 6, Q09011. https://doi.org/10.1029/2005GC000986.

van den Bogaard, P., 2013. The origin of the Canary Island Seamount Province - new ages of old seamounts. Sci. Rep. 3, 2107. https://doi.org/10.1038/srep02107.

Van der Meijde, M. van der Lee, S., Giardini, D., 2003. Crustal structure beneath broadband seismic stations in the Mediterranean region. Geophys. J. Int. 152, 729-739. https://doi.org/10.1046/j.1365-246X.2003.01871.x.

Walker, G.P.L., 1999. Volcanic rift zones and their intrusion swarms. J. Volcanol. Geotherm. Res. 94, 21-34. https://doi.org/10.1016/S0377-0273(99)00096-7.

Walter, T.R., Troll, V.R., Cailleau, B., Belousov, A., Schmincke, H.U., Amelung, F., Bogaard, P.V.D., 2005. Rift zone reorganization through flank instability in ocean island volcanoes: an example from Tenerife, Canary Islands. Bull. Volcanol. 67, 281-291. https:// doi.org/10.1007/s00445-004-0352-z.

Watts, A.B., 1994. Crustal structure, gravity anomalies and flexure of the lithosphere in the vicinity of the Canary Islands. Geophys. J. Int. 119, 648-666. https://doi.org/10.1111/ j.1365-246X.1994.tb00147.x.

Wilson, J.T., 1973. Mantle plumes and plate motions. Tectonophysics 19, 149-164. https:// doi.org/10.1016/0040-1951(73)90037-1.

Zazo, C., Goy, J.L., Hillaire-Marcel, C., Guillot, P.Y., Soler, V., González, J.A., et al., 2002. Raised marine sequences of Lanzarote and Fuerteventura revisited - a reappraisal of relative sea-level changes and vertical movements in the eastern Canary Islands during the Quaternary. Quat. Sci. Rev. 21 (18-19), 2019-2046. https://doi.org/10.1016/ S0277-3791(02)00009-4. 